\title{
OYSTER CULTURE IN EUROPEAN COUNTRIES
}

\author{
M. Héral and J. M. Deslous-Paoli
}

\section{TABLE OF CONTEN'TS}

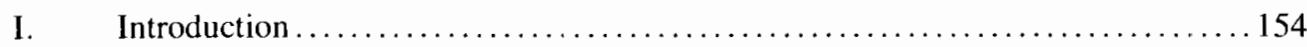

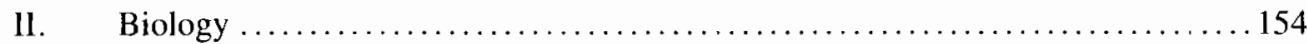

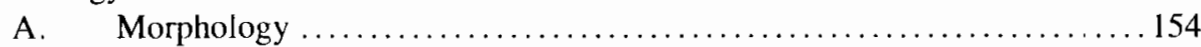

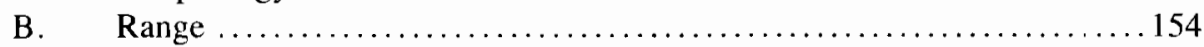

C. Salinity and Temperature Tolerances .......................... 155

1. Larvae .......................................... 155

2. Juveniles and Adults ............................... 155

D. Types of Substrate..................................... 157

E. Sexual Development and Spawning ............................ 157

F. Larval Development ...................................... 158

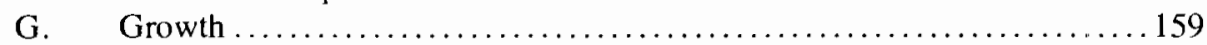

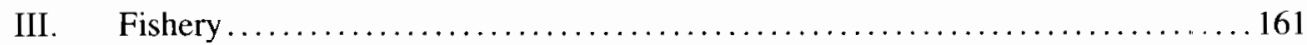

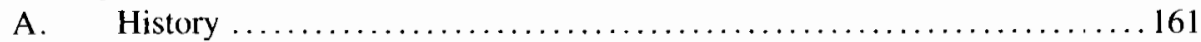

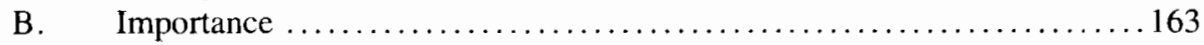

C. Recruitment and Methods of Culture ......................... 166

D. Methods of Harvesting .................................. 170

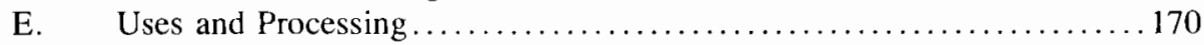

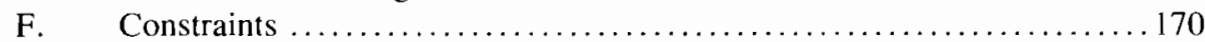

1. Diseases and Parasites ................................... 170

2. Predators and Competitors ............................... 173

3. Pollution ............................................ 173

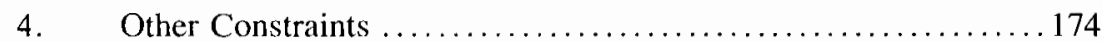

G. Management........................................... 175

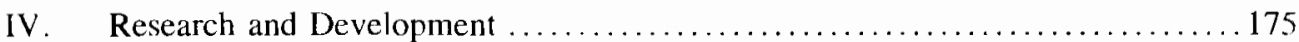

A. Introduction .......................................... 175

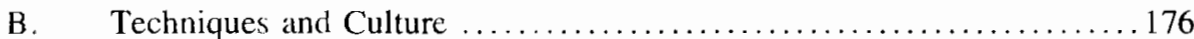

C. Pathology........................................... 177

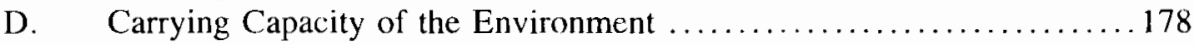

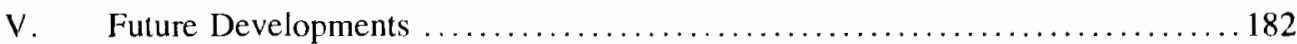

References..................................................... 186 


\section{INTRODUCTION}

Three species of oysters have been or are cultivated in Europe: Crassostrea angulata, C. gigas, and Ostrea edulis. If we follow the taxonomic critera of Grassé,' the European oysters belong to the group of Mollusca, class of Lamellibranchia or Bivalves, order of Filibranchia, family Ostreidae with two genera: $C$. angulata (Lamarck), Portuguese, cupped oyster; C. gigas, (Thunberg), Japanese or Pacific, cupped oyster; Ostrea edulis (Linné), flat European oyster.

Some authors think that $C$. gigas and $C$. angulata belong to the same species. Indeed, Ranson $^{2,3}$ stated that the characteristics of the larvae are the same, and Menzel ${ }^{4}$ obtained viable hybrids $\left(\mathrm{F}_{2}\right)$ between these two oysters. Also, Buroker et al. ${ }^{5}$ in studying the genetic variations of proteins and enzymes of the flesh, revealed a genetic similarity of $99 \%$ between C. gigas and $C$. angulata on 24 loci. These authors proposed the hypothesis that Japanese oysters would have been imported from Japan to Portugal by boats in the 16th Century or vice versa. However, these two oysters obviously show different characteristics in the metabolic rate,${ }^{6}$ the filtration rate, ${ }^{7}$ growth performance, ${ }^{6-9}$ reproduction mode, ${ }^{9}$ and resistance to disease. ${ }^{10}$ All these iatter elements combine to affirm that the Portuguese and the Japanese oysters are two species with well-defined physiological characteristics, particularly with regard to oyster culture.

\section{BIOLOGY}

\section{A. MORPHOLOGY}

The cupped oysters (Crassostrea) have a shell longer than it is broad with chalky deposits divided into sheets. The left valve is cupped (Figure 1). The right valve for the gigas oyster is flat, more irregular, and can sometimes be curled or scaly. The flat oyster (Ostrea) has a rounded or oval shell, cemented on the left valve, which is more curved (Figure 2). In both oysters, the flesh is covered by a tegument, the mantle (Figures 1 and 2 ). The free space between the two lobes of the mantle is the pallial cavity, which the gills divide into an inhalant and an exhalant part. The mouth, surrounded by the labial palps, is near the hinge, whereas the anus is just above the adductor muscle (Figures I and 2).

\section{B. RANGE}

Before diseases, which comprised the range of the flat species particularly on the Atlantic coast, $O$. edulis, the native oyster, was abundant in several European countries: from Norway, Denmark, the Netherlands, Germany, Belgium, France, Great Britain, and Ireland in the north, to the south Atlantic coast in France, Spain, Portugal, and Morocco, and the Mediterranean and Adriatic coasts of France, Italy, Yugoslavia, and Greece. It is or was cultivated mainly in France, the Netherlands, Spain, and to a lesser degree in the U.K. and Ireland.

C. angulata is still present in Portugal and the south of Spain. Introduced in France in 1866, this oyster was cultivated largely in this country until 1966 to 1970, when two diseases stopped production. This species seems to be still present on the Adriatic coast of Italy.

C. gigas has taken the place of the Portuguese oyster in European culture since 1970. It was cultivated first in France with adults imported from British Columbia (Canada) and spat from Japan. Nowadays, the only cultivated cupped oysters produced in European countries are $C$. gigas. There is a natural breeding ground only along the southwest part of the French Atlantic coast. This species is beginning to be cultivated in several other countries, such as Great Britain, Ireland, Denmark, Germany, Norway, Spain, and Italy, that have hatcheries to produce seed. 


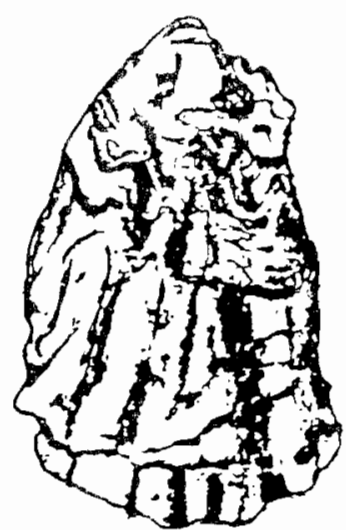

Upper valve

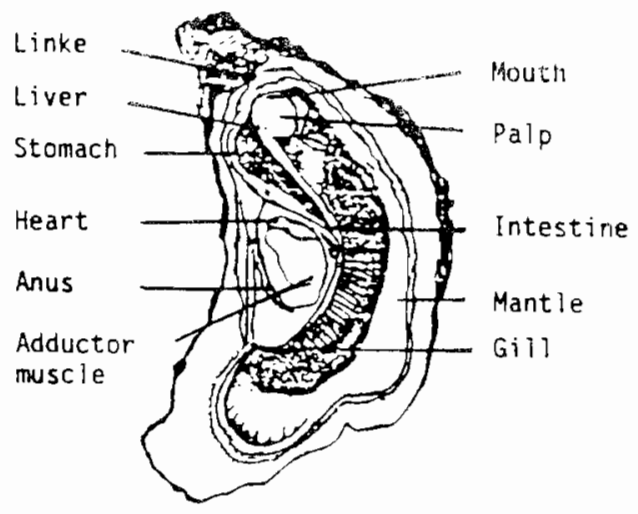

FIGURE 1. Anatony of the cupped oyster, Crassostrea gigas.
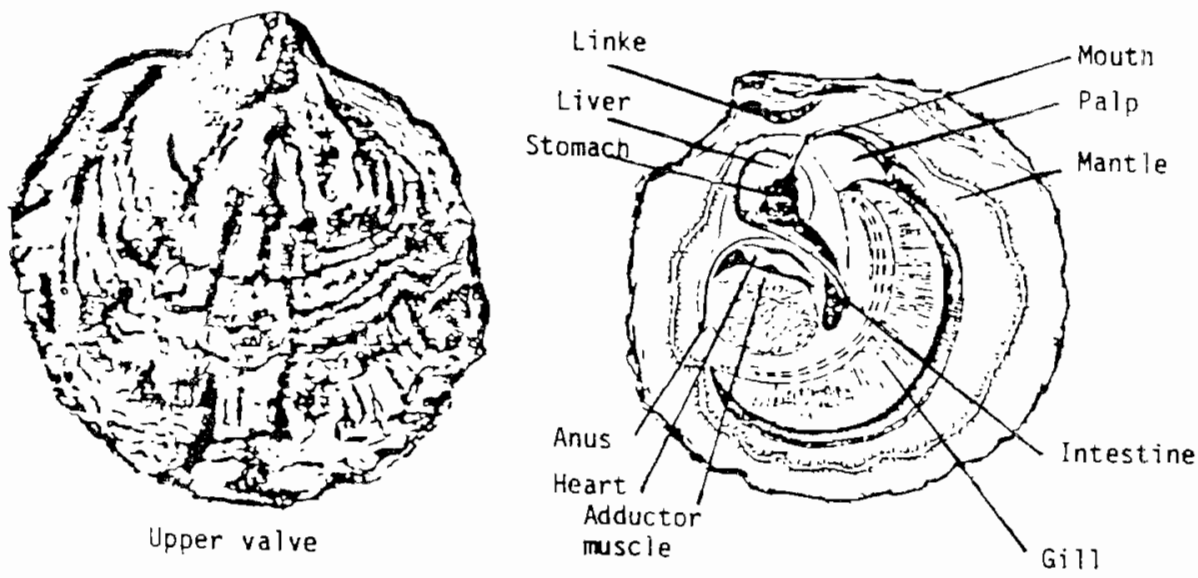

FIGURE 2. Anatomy of the flat oyster, Ostrea edulis.

\section{SALINITY ANI TEMPERATURE TOLERANCES}

\section{Larvae}

On the Atlantic coast, the reproduction of $C$. gigas occurs in July and August in European countries. The temperature must be above $18^{\circ} \mathrm{C}$ with an optimum at 21 to $22^{\circ} \mathrm{C}$, and the salinity can vary between 25 and $35 \%$. The higher the salinity is, the higher the temperature needs to be. Larval production is compromised when temperature is under $18^{\circ} \mathrm{C}$ and salinity above $34 \%$ (Figure 3).

In the lagoons on the Mediterranean coast, when in summer the temperature reaches 24 to $25^{\circ} \mathrm{C}$ and the salinity 37 to $38 \%$, C. gigas does not reproduce; nor does it reproduce in the open Mediterranean Sea where salinity is nearly $37 \%$ and temperature in the range of 19 to $22^{\circ} \mathrm{C}$, although in the Adriatic Sea, where the salinity is lower, reproduction occurs. $O$. edulis spawns in July, with larvae incubated in the mantle cavity. The salinity should be in the range of 25 to $36 \%$, " but otherwise does not interact with the temperature, which can vary from 14 to $22^{\circ} \mathrm{C}$; there is no larval development under $14^{\circ} \mathrm{C} .{ }^{9} \mathrm{O}$. edulis reproduces regularly in the Mediterranean gulfs, which permits a new oyster culture in open waters.

\section{Juveniles and Adults}

Temperature and salinity conditions determine species distribution not only for breeding, 


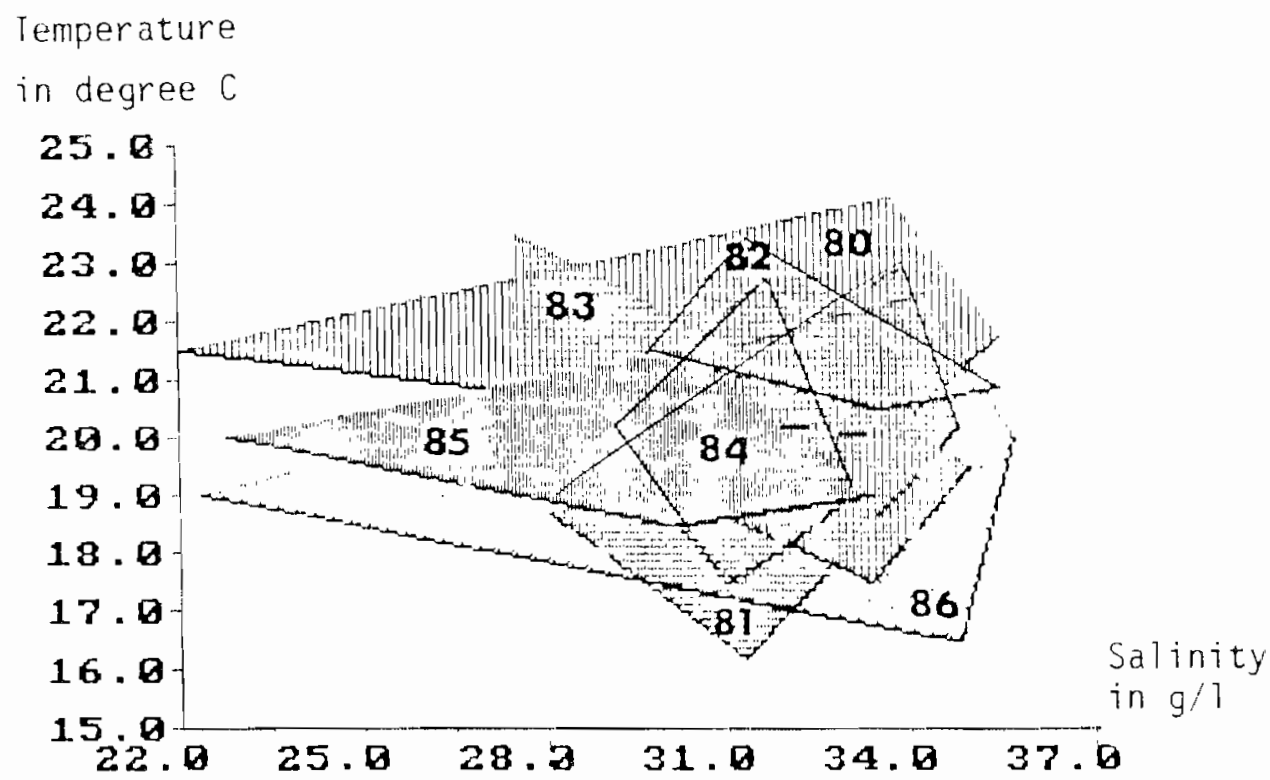

FIGURE 3. Temperature, salinity diagram of the bay of Marénnes-Oléron during the evolution of the larvae of the Japanese oyster (1980 to 1986). (From Héral, M., Aquaculture, Lavoisier, Paris, 1986, 346. With permission.)

but also for growing. C. gigas is a very euryhaline species that can be cultivated not only in oceanic waters, but also in upper estuaries with a mean salinity of $15 \%$ with variations between winter- and summertime of 2 to $25 \%$ (the Gironde estuary on the Charente Riber, for example). It can even be cultivated in salt marsh ponds or in "claires" in salinities that can reach 45 to $50 \%$. Above $50 \%$ of salinity, mortalities are observed. On the other hand, for the Japanese oyster, growth and fattening is affected by a mean salinity lower than $15 \%$. The oyster can persist for several weeks in wintertime when rivers are in spate, even in freshwater, by closing its valves. On a tidal cycle, it has an active metabolism during high tide and stops its activity at low tide with the freshwater input. For $O$. edulis, the optimal salinity is between 32 and $37 \% 0 .{ }^{9}$ At $25 \%$, the species grows well. Under $20 \%$ and above $40 \%$, it becomes feeble.

As temperature is an important parameter which controls all phenomena in mollusk physiology - filtering activity, metabolism, and, thus, respiration and excretion---Héral et al. ${ }^{12}$ demonstrated that if the egg-laying period is excluded, temperature is the primary explanatory factor for shell growth and the third explanatory factor for meat production in C. gigas. This oyster can have quite a high level of filtration even when temperature is at $5^{\circ} \mathrm{C},{ }^{13}$ whereas the filtration activity for the flat oyster is reduced at 8 to $10^{\circ} \mathrm{C}$. In wintertime, the indirect effect of ice on the oyster beds can cause high levels of mortality as the mechanical action of the ice breaks the young oysters off the collectors and carries them away with the floating ice. Freezes can cause direct mortality by tearing up the muscle with ice crystals or by bursting the shell.

High temperature in summertime, during reproduction, can bring about physiological disorders which cause mortality. In one sample, on the south Atlantic coast of France, the summer mortality rate for Pacific oysters was $20 \% .{ }^{14}$ Death occurred mostly among 1-yearold oysters, before spawning, with the temperature higher than $21^{\circ} \mathrm{C}$. A thinning of the digestive tubule epithelium was observed, but without evidence of infectious disease. Contrary to the observations of Mori ${ }^{15}$ for specimens in Japan and Perdue et al. ${ }^{16}$ for ones in America, the mortality did not appear to be related to the eutrophication of water and a high 
TABLE 1

Quantities (Q) and Percentage (\%) of the Dry Flesh (ng), the Energy (kJ) and the Proximate Constitution of the Flesh Lost by Males $(0)$ and Females $(i)$ during the Emission of Gametes

Oysters Collected during 1978

\begin{tabular}{|c|c|c|c|c|c|c|c|c|c|c|}
\hline \multirow{3}{*}{$\begin{array}{l}\text { Year } \\
\text { Sex }\end{array}$} & \multirow{2}{*}{\multicolumn{2}{|c|}{$\frac{1979}{\delta}$}} & & & \multirow{2}{*}{\multicolumn{2}{|c|}{$\begin{array}{l}1980 \\
N^{\mathrm{a}} \\
\end{array}$}} & \multicolumn{4}{|c|}{1981} \\
\hline & & & \multicolumn{2}{|c|}{ ? } & & & \multicolumn{2}{|c|}{$\delta$} & \multicolumn{2}{|l|}{ 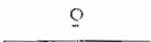 } \\
\hline & $\mathbf{Q}$ & $\%$ & $Q$ & $\%$ & $\mathbf{Q}$ & $\%$ & $Q$ & $\%$ & $\mathbf{Q}$ & $\%$ \\
\hline Dry weighı (mg) & 128.2 & 17.8 & 447.4 & 43.1 & 810 & 42.9 & 1510 & 55.9 & 1930 & 61 \\
\hline Energy $(\mathrm{kJ})$ & - & - & - & - & 19.48 & 52.7 & 30.98 & 61.1 & 45.3 & 69 \\
\hline Proteins & 86.7 & 27.7 & 236.3 & 51.1 & 435.7 & 51.0 & 502.6 & 55.2 & 663.7 & 61 \\
\hline Lipids & 11.6 & 18.7 & 88.6 & 63.1 & 257.0 & 67.3 & 89.5 & 49.1 & 334.2 & 78 \\
\hline Free carbohydrates & 5.7 & 33.7 & 16.6 & 59.8 & 9.46 & 30.1 & 30.0 & 57.9 & 22.9 & 51 \\
\hline Glycogen & 14.3 & 44.3 & 11.5 & 39.0 & - & - & - & - & - & \\
\hline \multirow[t]{2}{*}{ Ash } & 4.1 & 4.4 & 42.6 & 32.3 & 66.1 & 27.7 & 151.8 & 40.5 & 125.5 & 36 \\
\hline & \multicolumn{4}{|c|}{$\begin{array}{l}\text { Calculated from } 24 / 7 / 79 \text { to } \\
21 / 8 / 79\end{array}$} & \multicolumn{2}{|c|}{$\begin{array}{c}\text { Calculated from } \\
15 / 7 / 80 \text { to } \\
25 / 8 / 80\end{array}$} & \multicolumn{4}{|c|}{$\begin{array}{l}\text { Calculated from } 20 / 7 / 31 \text { to } \\
\qquad 28 / 10 / 81\end{array}$} \\
\hline
\end{tabular}

a ND: nondetermined sex.

level of lipids bound to an overmaturation. Actually, it seemed to be a physiological disorder in relation to a deficiency of the energy balance of the oyster, limited to heat stress.

\section{TYPES OF SUBSTRATE}

At the end of the planktonic stage, cupped and flat oysters attach to hard natural substrates such as rocks, stones, gravels, and living or dead shells, or artificial substrates such as dikes, artificial reefs, etc. For cultivation, the spat are fixed on cultch, which can be limed or unlimed tiles, slates, oyster or scallop shell, plastic tubes, etc. The adult oysters, if they are cultivated in suspension, can stay on the collector until marketable size or can be detached and attached to wood or rope. For botton culture the oysters are either scraped from the collector and spread directly on sandy or muddy grounds or cultivated on tables and racks in plastic, iron, or wood bags or pockets.

\section{E. SEXUAL DEVELOPMENT AND SPAWNING}

C. gigas is an oviparous oyster with alternative protandry and a high level of fecundity. The oystcr is either male or female during a particular breeding season but can change sex the following year. A small percentage can remain hermaphroditic. ${ }^{17}$ The environment (temperature and nutrition) and hormonal factors seem to determine the percentage of sexual change. The Japanese oysters mature during the first year if they have reached a minimum size of $50 \mathrm{~mm}$. It appears (Table 1) that reproduction is a function of agc.

$O$. edulis has a restricted fecundity and is larviparous. It is hermaphroditic, with a consecutive rhythmic sexuality. Male and female gametes are not ripe at the same time. If we follow Marteil, ${ }^{9}$ the flat oyster is male in autumn; after spawning, remaining spermatozoids are lysed and the ovogonies develop for the next breeding season, when it becomes a female oyster. The sexual inversion is influenced by temperature and available food. Yonge $^{18}$ showed that in Scandinavia the flat oyster changed sex once a year, while in Great Britain and in France each oyster could be male or female several times the same summer. Fertilization in $O$. edulis occurs in the pallial cavity, where the larvae are incubated to an advanced stage before release ("swarming"). 


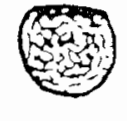

I

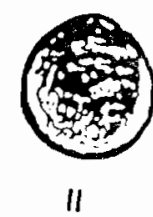

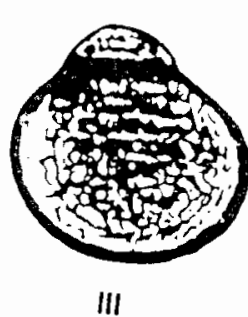

III

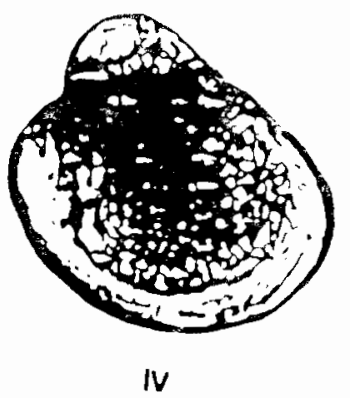

IV

FIGURE 4. The four stages in development of cupped oyster larvae. "7 French oyster biologists divide stage 1 into two: the straight hinged larva (24-h-old larva) and the very early umbo stage. (Hrom His, E. and Robert, R., Rev. Trav. Inst. Peches Marit., 47 ( 1 and 2), 63, 1985. With permission.)

The duration of sexual maturation is a function of the quantity of heat that the reproductive oyster receives. Muranata and Lannan ${ }^{19}$ showed that the mean value of day degree is nearly 2300 degree-days for $C$. gigas maintained experimentally at a temperature of 18 to $22{ }^{\circ} \mathrm{C}$ and salinities of 20 to $30 \%$. Mann ${ }^{20}$ demonstrated that gametogenesis began only above $10.55^{\circ} \mathrm{C}$. In addition, Héral et al. ${ }^{21}$ described how, for the Bay of Marénnes-Oléron, which is the main sector of reproduction of cupped oysters in the European Atlantic coast, C. gigas bred after 2287 degree-days: the date of spawning was dependent each year on temperature fluctuation, with $95 \%$ of spawning occurring between July 12th and August 21st. For the flat oyster, Martei ${ }^{9}$ found that the minimal temperature necessary for the beginning of gametogenesis is $10^{\circ} \mathrm{C}$, but only after a period of sexual rest, which is not required for the Japanese oyster.

The effect of temperature on the release of the gametes is also important. Lubet ${ }^{22}$ showed that there was a minimal critical temperature under which the emission of sexual products could not take place. For C. gigas it is 17 to $18^{\circ} \mathrm{C}$ and for $O$. edulis 14 to $16^{\circ} \mathrm{C}$.

Marteil $1^{9}$ reported that $O$. edulis delayed its gametogenesis in estuaries when the salinity was under $20 \%$, but variations between 30 and $36 \%$ did not seem to play a role in the clate of spawning and on the quantity of the gametes. For the Japanese oyster it seems that gametogenesis takes place sooner when the salinity is between 20 and $35 \%$.

C. gigas has complete spawning. In France, this oyster spawns mainly once in MarénnesOléron Bay, but in Arcachon, successive rebuildings of the gonads occur, with two or three spawnings depending on the heat of the summer. Provided the temperature is high enough, $O$. edulis can possibly have a phase of reconstitution of the gonads after the first estival laying, which permits another spawning in autumn. On the Adriatic coast, the spawning season is in March and April, but for the same species in Norway it occurs in August. These differences show the role of climatic conditions on the rapidity of gametogenesis and, consequently, the time of spawning.

When the sexual products are ripe, adult $C$. gigas eject their gametes (20 to 100 million eggs) in the water. After external fertilization by the spermatozoids, the ova develop into the trocophore larvae.

\section{F. LARVAL DEVELOPMENT}

For $C$. gigas the length of the youngest well-formed larva is nearly $60 \mu \mathrm{m}$, and the size at metamorphosis is circa $300 \mu \mathrm{m}$ (Figure 4) ${ }^{23-25}$ The duration of the larval life is in relation to the temperature. The time varies on the French Atlantic coast from 1.5 to $28 \mathrm{~d}$ at temperatures 20 to $26^{\circ} \mathrm{C}$. The optimal temperature for the shorter larval development was $28^{\circ} \mathrm{C}$ for a salinity of 30 to $32 \% .{ }^{26}$ At lower temperatures, the pelagic phase is lengthened. For 
TABLE 2

The Stages in the Development of the Larva of the Japanese Oyster Crassostrea gigas as Described by Oyster Biologists and Malacologists

Days after the fertilization

$$
\begin{gathered}
1-6 \\
6-18 \\
18-22 \\
22-24 \\
24
\end{gathered}
$$

Names uscd by malacologist

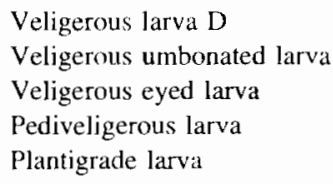

Height in $\mu \mathrm{m}$

$$
\begin{gathered}
57--105 \\
105-260 \\
260-280 \\
280--300 \\
300
\end{gathered}
$$

the flat oyster, the planktonic stage is from 5 to $14 \mathrm{~d}$ at temperatures from 17 to $26^{\circ} \mathrm{C}$. The size of the released larvae (mean $180 \mathrm{~mm}$ ) depends on the length of time the mother oyster retains them in the mantle cavity. Setting occurs when the size is between 280 and 300 $\mu \mathrm{m} .{ }^{24}$ All the spawnings do not result in settlements because for $C$. gigas the temperature must be higher than $18^{\circ} \mathrm{C}$ (Figure 3) and for O. edulis higher than 15 to $16^{\circ} \mathrm{C}$.

Helm and Millican ${ }^{28}$ showed that the optimal salinity for $C$. gigas is $25 \%$ for larval development. However, recruitment can be as good at $20 \% 0$ as at $35 \%$ and is more dependent on the temperature. The higher the salinity is, the more necessary it is for the temperature to be above $22^{\circ} \mathrm{C}$ (Figure 3). So, to aid in cultivation, twice a week each summer since 1930 biologists from fishery institutes such as IFREMER have analyzed the numbers and development of the larvae in places were oysters breed to predict the optimal times for the oystermen to immerse the collectors.

\section{G. GROWTH}

Substantial differences in the amount of growth are recorded not only from different sites in different countries, but also in the same site at different levels in exploilation of a bay (Tables 3 and 4). Thus, growth appears to be a function of temperature. In temperate regions, growth in wintertime is reduced, particularly for $O$. edulis under 8 to $10^{\circ} \mathrm{C}$. $C$. gigas is more tolerant of low temperatures, and when the level of food is high enough, winter growth occurs.

The main factor which increases or decreases the growth rate is the available food. This, in turn, depends on two factors. The first one is the nutritional value of the bay for the oyster, which is a function of the current velocity, multiplied by the quantity of food in the water and the time of immersion. Different bays, lochs, and cstuaries were tested in the U.K. ${ }^{35}$ and Ireland ${ }^{36}$ for $C$. gigas growth, and some sites showed growth ten times that of the others. In experiments such as these where the quantities of cultivated oysters are little and where there is no other large cultivation or wild population of mollusks in the area, the growth results indicate the level of the trophic capacity of each sector.

The second factor affecting growth is the impact of breeding density on the available food at two scales: the local density, which is the density of the unit of culture, and the total biomass of cultivated and wild population of mollusks in the area. It is well known that oyster growth relates to settlement surface. ${ }^{32}$ For this reason, spat produced free of support (in hatcheries) has a better growth than natural settlement unless the young oysters are scraped early from the collectors. This observation for juveniles is also valid for adults. Several authors have shown that growth was a function of the density on the ground, in baskets, or in racks. The impact in the rural biomass on the growth rate has been studied by Héral et al., ${ }^{6.38}$ who found that for the Bay of Marénnes-Oléron there is a slight correlation (Figure 5) between the decrease of the growth rate and the development of the total cultivated biomass of Pacific oyster for the last 15 years.

The maximal grow th of $C$. gigas occurred in Israel in subtropical fish ponds, ${ }^{39}$ with 
TABLE 3

Growth Performance of the Cupped Oyster Crassostrea gigas on the European and Mediterranean Coast

\begin{tabular}{|c|c|c|c|}
\hline Locality & $\begin{array}{c}\text { Total weight } \\
\text { after } 12 \\
\text { months (g) }\end{array}$ & $\begin{array}{c}\text { Total weight } \\
\text { after } 24 \text { months } \\
\text { (g) }\end{array}$ & Ref. \\
\hline Emsworth Harbour (U.K.) & $\begin{array}{c}34 \\
(5) 60\end{array}$ & 100 & 41 \\
\hline Newton Bay (U.K.) & 52 & & 29 \\
\hline Linne Mhiurich (U.K.) & 14 & 58 & \\
\hline Emsworth Harbour (U.K.) & 20 & $\begin{array}{c}70 \\
\text { (16 months) }\end{array}$ & 31 \\
\hline Menai Straits (U.K.) & 50 & 130 & 35 \\
\hline Rossmore (Ireland) & 46 & - & 36 \\
\hline Carlinglard & 16 & -- & \\
\hline Bullinakill & 6 & - & \\
\hline Carna & 3 & -- & \\
\hline Flensburg & & 60 & 42 \\
\hline $\begin{array}{l}\text { Baltic North Sea } \\
\text { (Germany) }\end{array}$ & $\begin{array}{c}8 \\
(12) 60\end{array}$ & & 43 \\
\hline Flensburg Fjord (Germ:ıny) & 24 & - & 44 \\
\hline Oualidia (Maroc) & (6) 43 & 120 & 37 \\
\hline Etel (France) & $12-29$ & - & 45 \\
\hline Marénnes-Oléron (France) & 48 & 60 & 46 \\
\hline Marennes-Oléron (France) & 35 & 60 & 47 \\
\hline Thau (France) & $35-50$ & $\begin{array}{c}68 \\
116 \text { (20 months) }\end{array}$ & 48 \\
\hline Corse (France) & - & 100 (17 months) & 49 \\
\hline Arcachon (France) & $\begin{array}{c}15 \\
\text { (18 months) }\end{array}$ & 58 (30 months) & 50 \\
\hline Marénnes-Oléron (France) & $\begin{array}{c}8 \\
\text { (18 months) }\end{array}$ & 27 (30 months) & \\
\hline Bretagne Sud (France) & $\begin{array}{c}28 \\
\text { (18 months) }\end{array}$ & 99 (30 months) & \\
\hline Marénnes-Oléron (France) & $\begin{array}{c}197050 \\
197233 \\
197420 \\
1975-1981 \\
20 \\
1984 \quad 15\end{array}$ & $\begin{array}{r}100 \\
75 \\
50 \\
40\end{array}$ & 6 \\
\hline Fish pond (1srael) & $\begin{array}{c}\text { (4) } 79 \\
92\end{array}$ & - & 39 \\
\hline Lim Canal (Yugoslavia) & 26 & 103 & 34 \\
\hline
\end{tabular}

Note: Number in parenthesis represents weight at the beginning of the culture.

high temperatures and food levels, where young oysters of $4 \mathrm{~g}$ reached 80 to $90 \mathrm{~g}$ in 1 year. The better growth in European countries is 40 to $50 \mathrm{~g}$ after 1 year and 100 to $130 \mathrm{~g}$ at the end of the second year of growth. This growth rate was found in England, ${ }^{29,35}$ in France when the stock density was low, ${ }^{36}$ and in Corsica and Morocco. ${ }^{37}$ For O. edulis, the better growth is observed in France on the Mediterranean coast with a weight of $60 \mathrm{~g}$ after 2 years of cultivation. This performance could be achieved also in French Brittany but with a seed density of 1 ton/ha, which is five times less than the traditional density.

The growth of the flesh expressed in dry weight of the meat in wintertime represents about $1 \%$ of the total weight and in summertime about 2.5 to $4.5 \%$. The dry weight of the flesh shows great variation (Figure 6) in relation to the reproduction and lack of food during wintertime. ${ }^{40}$ 
TABLE

Growh Performance of the Flat Oyster Ostrea edulis on the European and Mediterrauean Coast

$\begin{array}{cc} & \text { Total weight } \\ & \text { after } 12 \\ \text { months (g) }\end{array}$

(5) 30

(5) 30

15-20

10

4

-

$-$

$23--35$

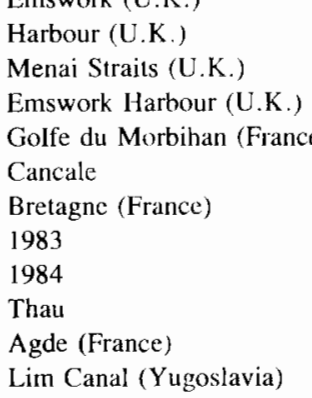

Agde (France)

Total weight
after 24 months (g)

Total weight after 36 months (g)

after 24 months (g)

$\begin{array}{cc}40-50 & 29 \\ 50 & 30 \\ & 3 ! \\ & 9 \\ & 32 \\ & \\ & 33 \\ 50 & 34\end{array}$

$\Delta g$ in $g$

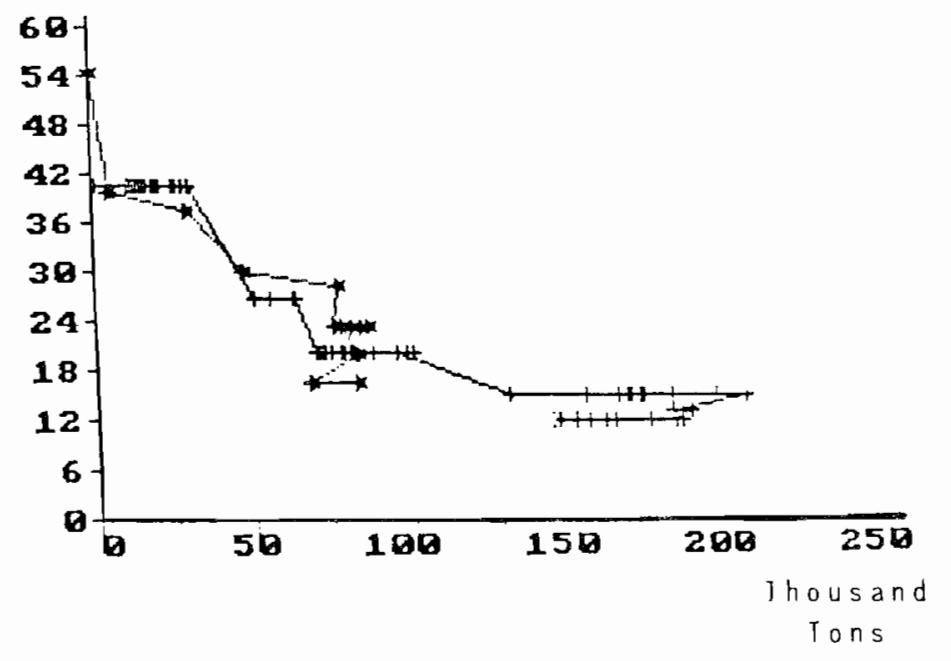

FIGURE 5. Evolution of the annual growth rate of Portuguese oyster $(+)$ and Japanese oyster $\left(^{*}\right)$ in relation to the total biomass of oysters in the bay of Marénnes-Oléron. (From Héral, M., Deslous-Paoli, J. M., and Prou, J., ICES, Mariculture Committee, F, 41, 22, 1986. With permission.)

\section{FISHERY}

\section{A. HISTORY}

The flat oyster $O$. edulis is the native European species, which was very common until the last century. Shallow bays and estuaries around the coasts of Europe, including Ireland and the Mediterranean, abounded in centuries past with oysters that could be picked by hand in many places at low water or dredged by boats, resulting in a prosperous oyster fishery. In ancient times, Romans built some ponds to stockpile the harvest and tried to collect the spat on wood fascines. During the Middle Ages and Renaissance, fisheries on the oyster 


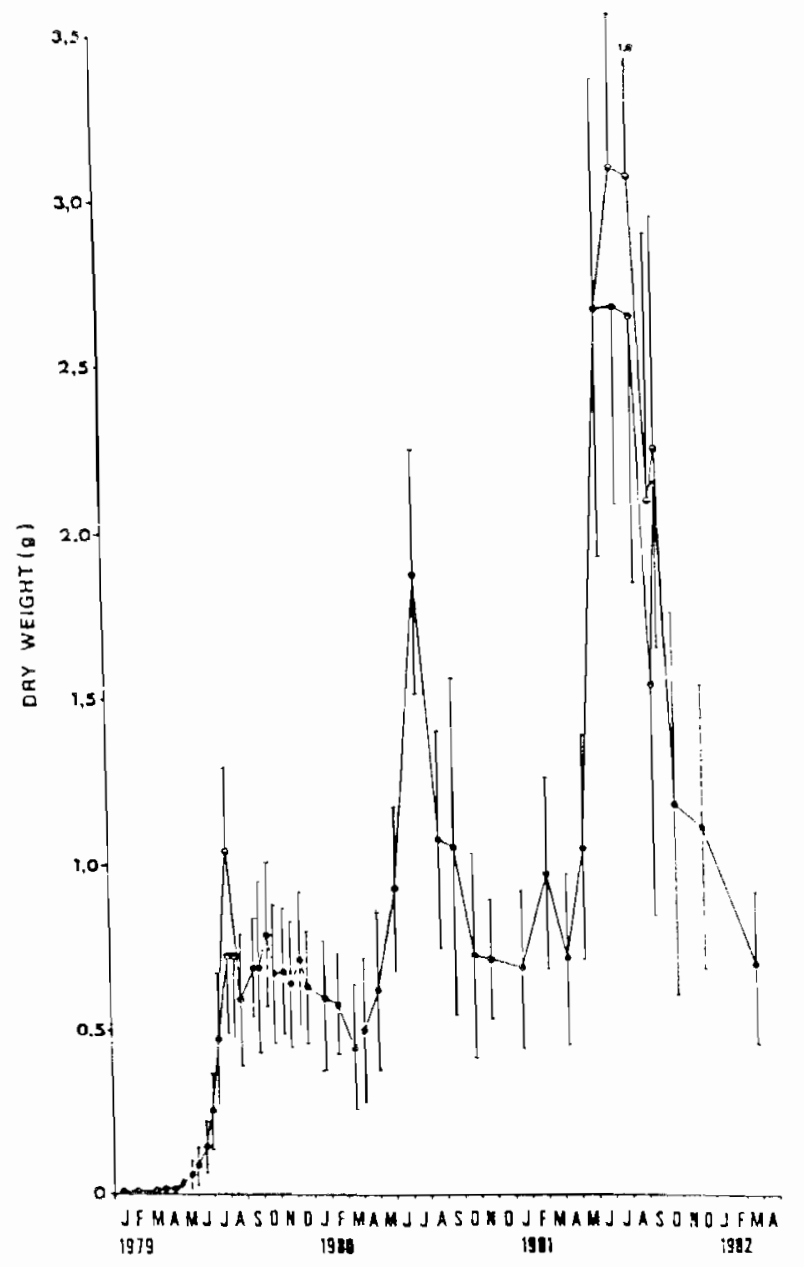

FIGURE 6. Evolution of the dry weight of Crassostrea gigas in the bay of Marénnes-Oléron. (From Héral, M., Aquaculture, Lavoisier, Paris, 1986, 346. With permission.)

beds went on. In the 18th Century, the increased population induced an increase in fishing efforts causing overfishing in the beds, whose production in preceding years had varied depending on the intensity of settlement. By the end of this century the oyster beds of France, Ireland, and England were largely overfished, and regulations were made to limit the fishing season and to suspend it altogether during the reproductive period

Despite these more and more constraining regulations, the fishing effort grew. Increased consumption was encouraged by the development of transportation of goods and by the beginning of oyster culture. At this period there was no real culture; the oysters were only kept in stocks in ponds before the sale. On the Atlantic coast, near La Rochelle, old unused salt marshes were turned into "claires" for finishing the growth and fattening the flat oysters. It was only after 1860 that in France the technique of cultches was begun by enlarging the Italian wooden fascines used by the Romans. Culture techniques advanced very quickly with new materials - slates and tiles with lime for settlement - and new culture methods, bottom and rack. In 1920 to 1921, a disease decimated the beds of flat oysters throughout Europe. It was only after 1928 that settlement began to be abundant again, particularly in French Brittany. In several localities (Marénnes-Oléron, Arcachon), the wild flat oyster beds had 
definitively disappearcd. In Irelaud, Great Britain, the Nethorlands, and the Mediterranean coast, some oyster beds persisted, and their exploitation by fishermen continued. In 1950 to 1951, a new disease appeared and destroyed the flat cultivated oysters of the Than lagoon. The breeding of $O$. edulis continued in French Brittany, which sold juveniles to Spain (Galicia) and to the Netherlands. After a phase of large expansion (annual French production of 30,000 ton; Figure 7), flat oysters were attacked again by two parasites-Marteilia refringens Combs (since 1974) ${ }^{51}$ and Bonamia ostreae Pichst and Coll (since 1979) ${ }^{52}$ - that spread to other European countries, reducing the breeding in France, Holland, and Spain.

Since the beginning of European oyster culture in 1860, cupped oysters had been imported to France from the Portuguese wild oyster beds to palliate the lack of flat oysters. During one of these trips a boat threw its cargo of oysters out in the estuary of Gironde, and the species $C$. angulata spread quickly on the southwest Atlantic coast of France. After 1920, yield from cupped oysters was almost equal to that of the flat oyster (annual French production of cupped oysters more than 85,000 ton; Figure 7). From 1966 to 1969, throughout the French coasts the Portuguese oysters wcrc infected by a gill disease and by an iridovirus that destroyed the species $C$. angulata in Europe. At the present time, only some oyster beds in Portugal are still active.

French importation of C.gigas, with spat from Japan and adults from British Columbia, occurred from 1968 to 1975 (Figure 8). Reproduction of Japanese oysters has been well established since 1971 on the southwest Atlantic coasts of France, and the level of production in this country has reached 100,000 ton since 1980. Other countries such as Great Britain, Ireland, Germany, Norway, Denmark, Spain, Italy, and Morocco have started very recently to cultivate $C$. gigas with spat produced mainly in hatcheries from Great Britain, France, or Ireland.

This brief historical study shows that during the last century, a constant series of events, particularly evident in France, manifested itself: first, overfishing of natural flat oyster beds followed by disease; second, importation of a foreign species ( $C$. angulata), bred on a large scale with high density and disease; third, inportation of a new exotic species (C. gigas) and cultivation at a high level.

Each time the response to mortality caused by disease has been the importation of the next species. It would be better to understand the disease and to practice management of oyster bays. Thus, it appears that diseases occurred after a period of high level of production, and we suggest the hypothesis that when the cultivation densities in a bay are too high, the trophic equilibrium is surpassed, growth and fattening decrease, and the defense mechanisms of the oysters are lowered. By controlling the stock in culture, the risk of disease could be lessened.

\section{B. IMPORTANCE}

Statistics to estimate the level of production in different countries are very often not realistic and cannot be compared with one another (see, for example, Héral et al. ${ }^{38}$ for validation of the French statistics on oysters).

The data from the last yearbook of Fishery Statistics published by the Food and Agriculture Organization (FAO) of the United Nations can give bases for comparison. For the cupped oyster, which is only the Japanese one, the European production from 1981 to 1984 varied between 78,000 and 105,000 ton of total living weight including the sheII. The French production represents $99 \%$ of the total production. For the flat oyster, the same source of data shows that the production is at a low level, around 4000 ton which represents only $4 \%$ of the quantity of the cupped oyster (Table 6). The French production (40\% of total), which was nearly 15,000 ton, is now 1800 ton because of the two diseases, Marteilia and Bonamia. The harvest of $O$. edulis in the Netherlands has increased to $20 \%$ of the total by the use of native oysters that are uncontaminated by diseases and have tolerance for low temperatures, instead of importing seed from France. ${ }^{29}$ 
Annual production
of oysters in tons

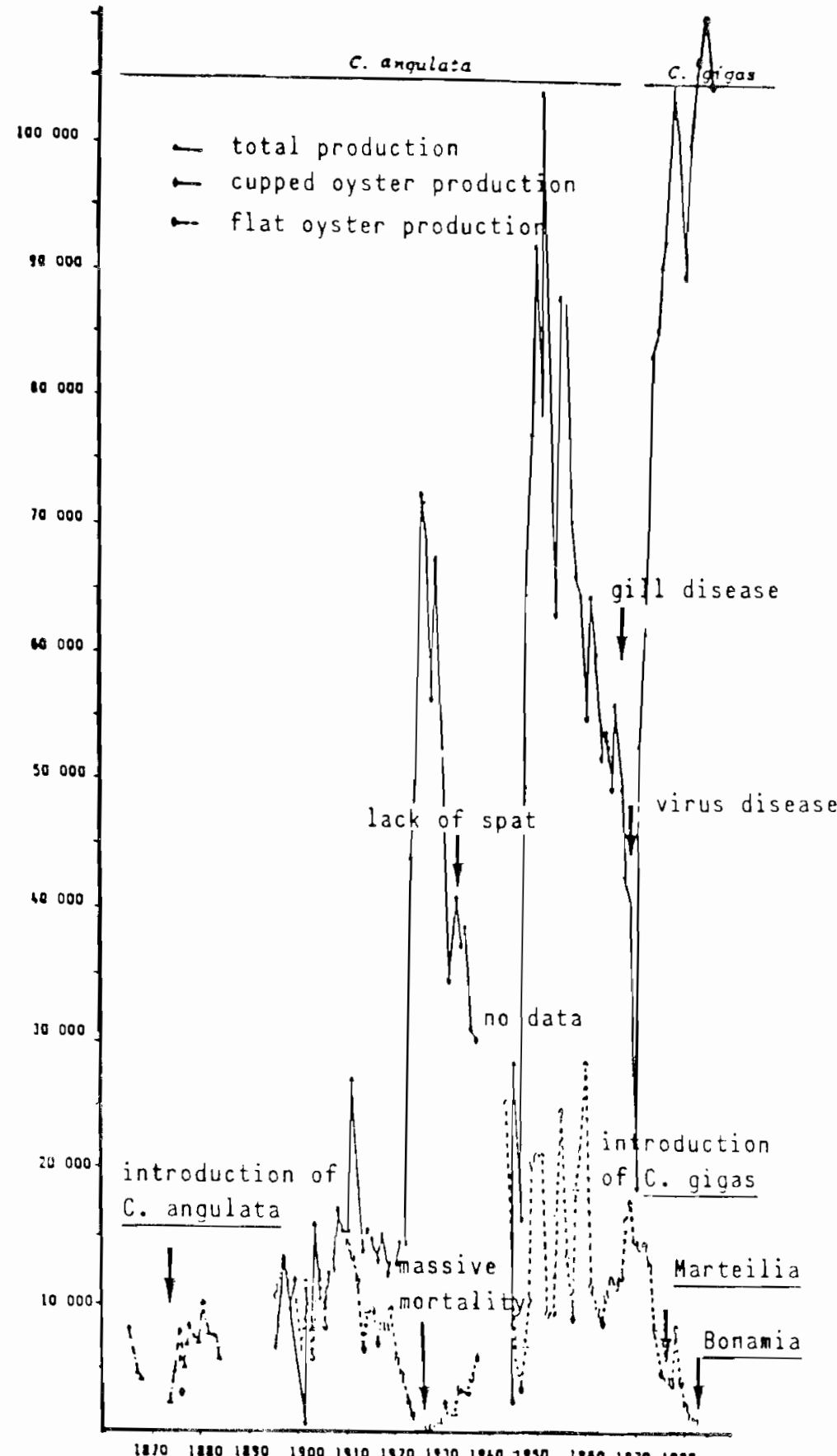

$11 / 0 \quad 18201130 \quad 190018101320183018401930 \quad 191818301980$

IFGURE 7. Evolution of the production of oysters in France from 1865 to 1985. (source: official statistics from Fisherics Department). (From Héral, M., Aquaculture, Lavoisier, Paris, 1986, 346. With permission.) 


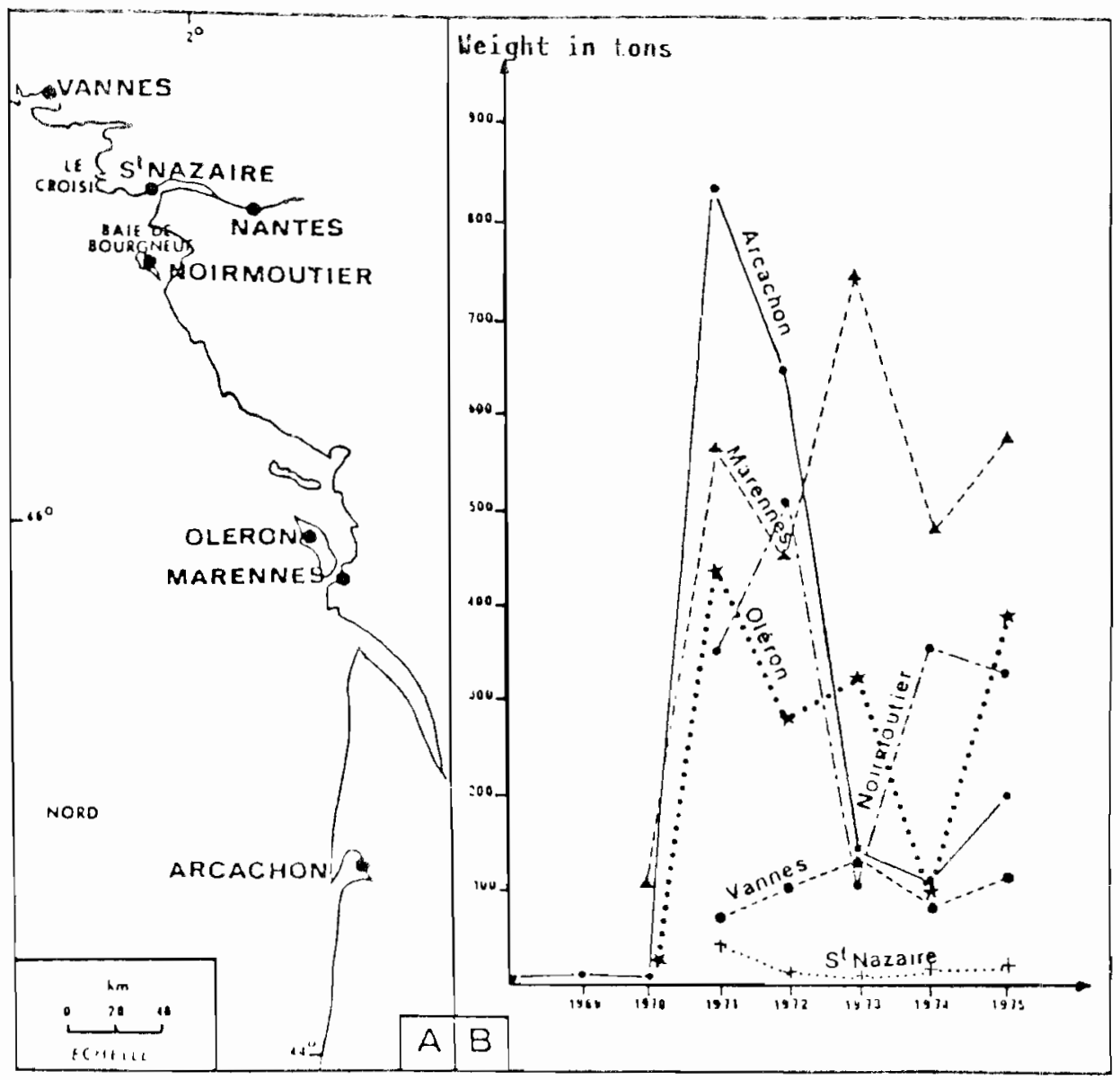

FlGURE 8. Quantities of spat (C. gigas) imported from Japan on the French Atlantic coast. (From Gruet, Y., Héral, M., and Robert, J. M., Cah. Biol. Mar., 17, 173, 1976. With permission.)

TABLE 5

Nominal Catches for Crassostrea gigas by Countries in Tons of Total Weight

$\begin{array}{lrrrr} & 1981 & 1982 & 1983 & 1984 \\ \text { France } & & & & \\ \text { Unitcd Kingdon } & 90,242 & 80,082 & 104,849 & 77,755 \\ \text { Germany } & 61 & 58 & 70 & 144 \\ \text { Total } & 1 & 1 & 1 & 1 \\ & 90,304 & 80,141 & 104,920 & 77,900\end{array}$

From Yearbook of Fishery Statistics, FAO Statistics Series, Vol. 58, Food and Agriculture Organization, Rome, 1986.

In a recent FAO paper on developnent of aquaculture in Europe (Table 7), it is predicted that by 1990 oyster production in France will stabilize; Italy, Spain, and the U.K. will increase; and Denmark, the Federal Republic of Germany, and Yugoslavia are expected to develop a culture.

It is mainly in France that oyster culture plays a large econonic role, with a production of oysters above 100,000 ton and with a value of nearly 1 billion francs ( $\$ 150$ million US). 
TABLL 6

Nominal Catches for Ostrea edulis by Countries in Tons of Total Weight

$\begin{array}{lcccc} & 1981 & \mathbf{1 9 8 2} & \mathbf{1 9 8 3} & \mathbf{1 9 8 4} \\ \text { France } & 3.242 & 7.059 & 1.369 & 1.773 \\ \text { Ireland } & \mathbf{4 0 0} & 861 & 316 & 371 \\ \text { Netherlands } & 572 & 560 & 680 & 843 \\ \text { Spain } & 280 & 539 & 549 & 560 \\ \text { Sweden } & 25 & 13 & 13 & 11 \\ \text { United Kingdom } & 560 & 399 & 269 & 360 \\ \text { Turkey } & 1 & 0 & 0 & 9 \\ \text { Yugoslavia } & 56 & 82 & 57 & 181 \\ \text { Total } & 5.136 & 9.513 & 3.253 & 4.108\end{array}$

From Yearbook of Fishery Statistics, FAO Statistics Series, Vol. 58, Food and Agriculture Organization, Rome, 1986

TABLE 7

The Aquaculture Production of Oysters in Tons of Total Weight and Estimates of Future Production

$\begin{array}{lrrrr} & \mathbf{1 9 8 0} & \mathbf{1 9 8 3} & \mathbf{1 9 8 5} & \mathbf{1 9 9 0} \\ \text { Denmark } & & & & \\ \text { Federal Republic of Germany, Japanese oyster } & 0 & 15 & 30 & 60-100 \\ \text { France, flat oyster } & 0 & 0 & 10-20 & 50 \\ \quad \text { Japanese oyster } & 4,170 & 1,288 & 2,300 & 4,000 \\ \text { Ireland, flat oyster } & 95,165 & 107,779 & 105,000 & 110,000 \\ \text { Italy, flat and Japanese oyster } & 60 & 35 & - & - \\ \text { Netherlands, flat oyster } & - & - & 1.000 & 3,000 \\ \text { Norway, Japancse oyster } & - & 1,000 & 1,500 & - \\ \text { Spain, flat oyster } & 0 & 30 & 50 & 1,000 \\ \text { United Kingdom, flat and Japanese oyster } & 1,700 & 2,350 & 3,000 & 4,000 \\ \text { Yugoslavia, flat oyster } & 800 & 800 & 800 & 1,200 \\ \text { Total } & - & 30 & 40 & 100 \\ & 101,895 & 113,312 & 113,735 & 123,430\end{array}$

From Ackefors, H., Muno, A., Müller, F., and Querellou, J., Development of Aquaculture in Europe, lAO ERC, 4, Food and Agriculture Organization, Rome, 1986, 31.

This represents one fifth of the total French marine production value. The permanent employment for oyster culture is about 10,000 , and more than 30,000 seasonal jobs are created in 5000 industries. ${ }^{5 *}$ The number of permanent jobs represents one third of the fisheries employment. This activity, when concentrated in some bays or estuaries, plays a high social importance and is very often the primary activity in these places. There are many satellite jobs in the plastic industry-factories for crates, for boats, for tools, for special machines, and so on. The evolution of the costs of production since 1970 in constant francs shows a diminution or stagnation in relation to the increase in cupped oyster production, caused by the allocation of new areas for breeding and the conversion of flat oyster to Japanese oyster cultivation. Because of mass production of $C$. gigas, there is an oversupply, and new markets must be developed.

\section{RECRUITMENT AND METHODS OF CULTURE}

A steady supply of seed oysters can be realized in three ways: regulated fisheries of juveniles on natural oyster beds, settlement of the spat on cultch, and production of cultchless seed lyy hatcheries and nurseries. 
TABLE 8

Main Hatcheries Producing Spat from Crassostrea gigas and Ostrea edulis in European Countries

Name

SATMAR

HEPC

Aquamare

Tina Menor

Planta de cultivos marinos

Conwy laboratory

Seasalter shellfish

Boet-mor/seafood
Address

La Salive Gatteville-phare

50760 BARFLEUR (France)

Le Varquez

29226 Carantec

Route diette

17590 Ars en Ré (France)

Pesues Cantabria (Spain)

Muelle de Parcillan

Ribadeo galicia (Spain)

Fisheries Experiment Station

Benorth Road

Conwy, Caernarvonshire (U.K.)

Ltd. The Harbour

Whistable Kent

Cus-Hastrough Gladdaghduff

Co Galway (lreland)
Level of production

Commercialized 80 million in 1983

Commercialized 18 miltion in 1986

Commercialized $1-5$ million

Commercialized 15 million

Experimental

Experimental

Commercialized

Conmercialized

The controlled population of oyster spat in experimental hatcheries has been well known since the work of Loosanof and Davis ${ }^{59}$ and Walne. ${ }^{60}$ The hatcheries have three main objectives: to produce seed when techniques for settlement are not known, to produce seed when the species do not reproduce in the area or reproduce only sporadically, and to practice genetic selection.

In Europe, as the natural spatfall is abundant for the cupped oyster and the flat oyster, the hatchery production remains small. Lucas ${ }^{61}$ gives (Table 8 ) a list of hatcheries. These hatcheries, in the future, could play a large role for production if researchers of genetic selection are successful in obtaining new races (triploids, for example) with better growth. Cultchless oysters present technical advantages for better growth, as the density can be controlled. The higher price of this seed, ten times more than that from natural settlement, allows a large development only for countries without natural recruitment (U.K., Spain, etc.) Occasionally in France, when there is a lack of spat due to abnormal weather conditions ( 1 to 2 years out of 10 ), the hatcheries can partially make up for the deficient seed.

C. gigas is indifferent to the type of substrate to which it attaches. This explains the large diversity of the cultches. The only requirement is that the collectors must be clcan, without fouling or silt, so they must be placed at just the right time before settlenent. For cupped oysters the old use of stones is practiced less and less, and the wood stakes and fascines are obsolete. Limed tiles are used particularly in the Areachon Bay, allowing an early removal of juveniles. Seed-collecting techniques have been developed over the years involving different kinds of collecting devices; metallic bars, slate, and oyster and scallop shells are often used. The shells are either placed in bags or strung on iron rods or wires. For the last 10 years plastic collectors have taken the place of the traditional collectors, especially with tubes used in packets of seven (Figure 9). Machines for removing seed have been used with tubes for the last 3 years

Flat oysters are morc selective of the cultch to which they attach. Spat collectors are usually tiles coated with a layer of lime mixed with sand. The composition of the lime is different for each bay and is described more precisely by Marteil. ${ }^{9}$ The main advantage of using limed collectors is that oysters can be removed from the collectors after 6 to 10 months. In French Brittany, a new collector made of mussel shells stuffed in bags or tubular nets is nearly as efficient for cultivation in open waters, ${ }^{62}$ with a very low cost of under 0.011 francs 


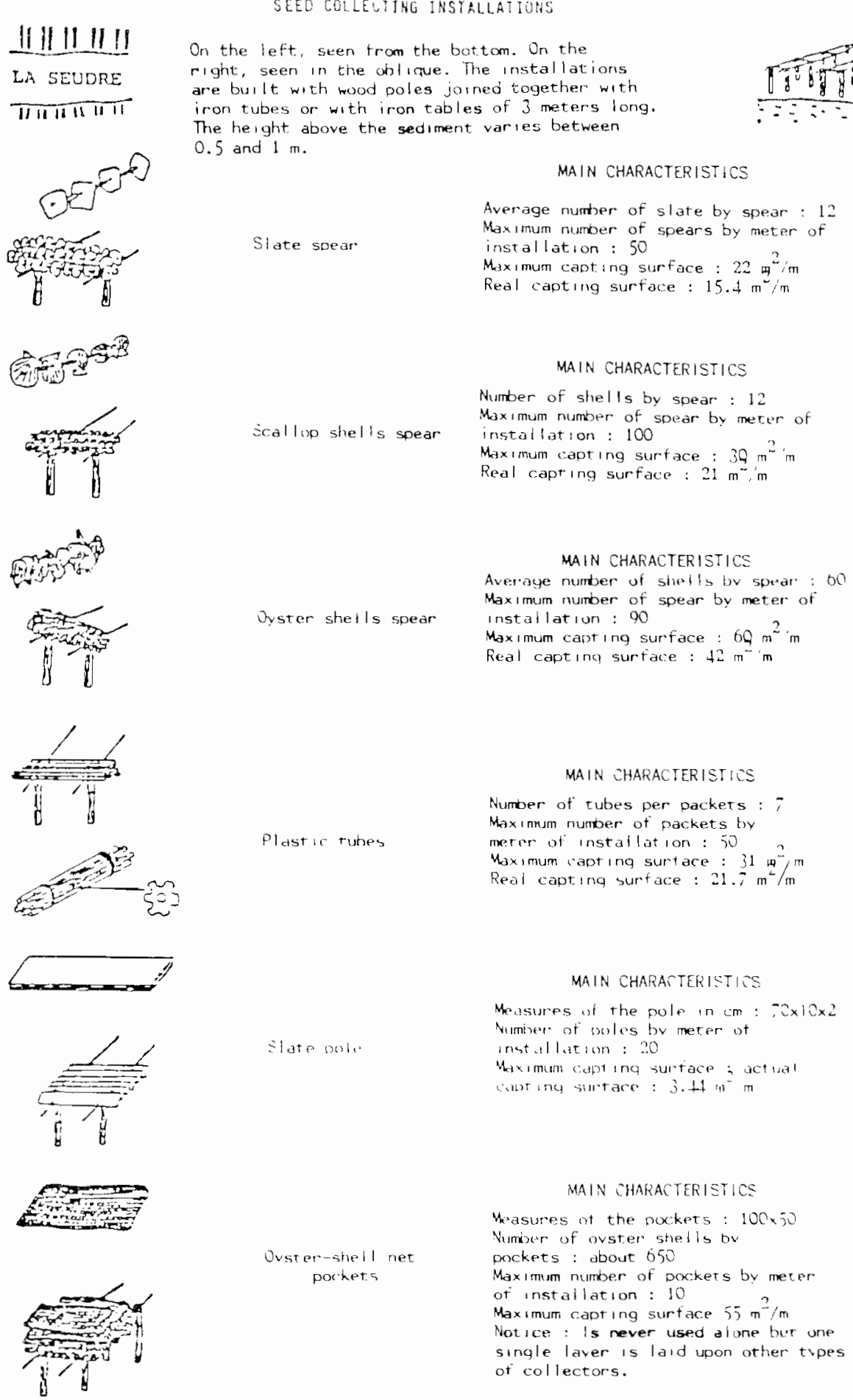

FIGURE 9. Different types of collectors used in the basin of Marénnes-Oléron. (From Berthomé, J. P., Prou, J., Razet, D., and Garnier, J., Haliotis, 14, 39, 1984. With permission.) 
hy unit in comparison with 0.06 franes per unit with tiles. Sampling has been done on the number of collectors used in the main bays to estimate the recruitments and predict the potential production that can be obtained in years to corne. In the Arcachon Bay, nearly 5 billion young oysters settle eath year, while an average of 10 billion spat are procuced in the Bay of Marénnes-Oléron, furnishing the entire French production of cupped seed oysters.

After the seed collection, oyster culture is carried out in two phases: pregrowing and maturing phase. A variety of techniques are used, with the duration of each phase depending on the growth rate and on the cultural peculiarities of each bay." The three mair oyster culture methods used in Europe are bottom culture, rack culture, and hanging-rope culture.

Bottom culture is carried out in intertidal zones as well as in deep water. The ground is hardened, if necessary, and the young oysters are sown on the ground attached or not to the collectors. In the intertidal zones, to protect the oysters against crabs, plastic wire fences with or without wooden planks are placed around the beds. This pregrowing can last 1 or 2 years. During the maturing period all the oysters are scraped from the cultch, sorted by weight, and sown again on maturing beds, which can be protected against the storms by fences made with wood sticks $5 \mathrm{~m}$ high (in Arcachon). The mean densities for the cupped oyster are $5 \mathrm{~kg}$ (total weight) on a square meter for the pregrowing and $7 \mathrm{~kg}$ (total weight) for the maturing phase. For the flat oysters before the diseases, Marteil ${ }^{9}$ indicated densities of $0.5 \mathrm{~kg}$ for the first year, $1 \mathrm{~kg}$ the second year, and 3 to $5 \mathrm{~kg}$ the third and fourth years. During growtl, oysters are regularly harrowed or turned over with oyster forks. The average yield for cupped oysters is estimated as 1 ton of spat producing 20 ton; for flat oysters 1 ton of spat generally produces 12 to 15 toll after 3 years of cultivation.

In deep water along the coast of Brittany and Holland, the flat oysters are planted at a depth ranging from 3 to $10 \mathrm{~m}$ after dredging for stones, predators, and competitors. Before the diseases, the density was $0.5 \mathrm{~kg}$ for 1 -year-old oysters and 0.7 to $0.9 \mathrm{~kg} / \mathrm{m}^{2}$ for 2-yearold oysters. Now the densities are five times less $\left(1 \mathrm{~kg} / \mathrm{m}^{2}\right)$, allowing optimal growth so as to avoid the large mortality rate caused by Bonamia that occurs in the third and fourth year. Cupped oysters are also cultivated in deep water, particularly since the decline of the production of Mlat oysters, at a density of 2 to $3 \mathrm{~kg} / \mathrm{m}^{2}$. Even with high mortality (duc to storms and predation), the mean yields are better than in the intertidal oyster beds and with a lower cost, but a higher investment (dredging boat).

The most common culture used at the present time along the French Atlantic littoral is the rack culture on iron tables. The tables are generally $3 \mathrm{~m}$ long and $0.5 \mathrm{~m}$ above the ground. In the intertidal oyster beds, the collectors are fixed to a row of tables at a high density (50 to 100 collectors per meter) (Figure 9). A year later, they are thinned oult to a density of 8 to 10 collectors per meter. After scraping, the juveniles are sorted and put in containers. The most common are plastic packets with a standard size of $1 \mathrm{~m} \mathrm{long}, 0.5 \mathrm{~m}$ wide, and $0.1 \mathrm{~m}$ deep. The mesh size depends on the size of the seed. The weight per bag is $5 \mathrm{~kg}$ for flat oysters and on average $10 \mathrm{~kg}$ for cupped oysters, but varies with the age of the oyster: $5 \mathrm{~kg}$ per bag for the youngest and $18 \mathrm{~kg}$ for the oldest. Rows of tables (30 to $100 \mathrm{~m}$ ) are placed parallel to each other. To avoid too great a density of oysters, the cultured tables should not total more than 1/3 of the leased area. One hectare should not have more than 6000 to 7000 oyster packets.

In the hanging method, the oysters are fixed on different supports: ropes, nets, and iron or wooden bars. These are hung from fixed tables or floating rafts. Fixed installations are mainly used in Mediterranean lagoons where there is no tide and quite a large depth (10 $\mathrm{m})$. The metallic tables are $50 \mathrm{~m}$ long and 10 to $12 \mathrm{~m}$ wide. Each table has about 50 wooden or metallic bars which carry about 1000 supports. ${ }^{64}$ The collectors of $C$. gigas coming from the Atlantic are directly hung under the table. Part of the oysters are harvested after 12 to 18 months; the rest may be stuck on wooden bars with quick cement and harvested $\mid$ year later, giving large and fat oysters. The average yield is 5 to 7 ton per table. The oysters 
can also be cultivated on floating raf!s (like those used in Spain for mussels). In Galicia, the "batea" is also used for flat oyster production. In Corsica, the same ratis are used for the cultivation of Japanese oysters. There have been some experimental cultures of flat oysters in suspension in Brittany and on the Mediterranean coast in places where the diseases Marteilia and Bonamia are not present.

\section{METHODS OF HARVESTING}

The harvest in the intertidal area is done by hand. For bottom cultivation, oysters are fished with oyster forks, put into baskets at the low tide, and at flood tide loaded onto flatboats. The yield is not more than 1.5 ton per man per tide. For rack culture on tables, the harvest is not mechanized, but the work is easier and faster. It consists of detaching the pockets from the table and loading them on flatboats. The yield depends on the size of the oyster beds. The average yield can be estimated at 200 pockets a day per tide, or nearly 3 ton.

In the subtidal areas, the oysters are dredged with special boats. ${ }^{9}$ The yield is very high -10 ton/h-but the daily yield is not more than 15 ton after taking the access time and the unloading time into consideration. After harvest, oysters are washed with machines and sorted by weight, by hand or mechanically. The oysters will either be prepared for the market or cultivation will be finished by a fattening phase. Fattening developed particularly in the bay of Marénnes-Oléron in old salt marshes converted since the 17th Century, to oyster ponds called "claires". In these shallow $(0.4 \mathrm{~m})$ earth ponds, the seawater cornes in by gravity during high tide only during the spring. In these "claires", there is a high level of phytoplankton productivity related to the input of a high level of nutrients in the estuarine waters and a low level of turbidity. However, to obtain fattening, the densities of oysters nust be under 10 oysters per square meter, which represents a biomass of 0.8 to $1 \mathrm{~kg} / \mathrm{m}^{2}$. As there is no water change during the neap tide $(10 \mathrm{~d})$, the phytoplankton bloom is very quickly grazed if the biomass of mollusks is too high. At a density of 20 oysters per square meter, there was no fattening and, indeed, a decrease in the weight of the flesh. ${ }^{65}$

In these claires, a phytoplanktonic algae bloom, Navicula ostrearia Bary, occurs. At the death of the cell, the green pigment diffuses in the waterst and is absorbed by the gills of the oyster, giving them a special dark-green color that is in demand. The blooms of $N$. ostrearia are attributed to the excretion of organic nitrogen by the oysters. ${ }^{67}$

\section{E. USES AND PROCESSING}

In European countries, oysters are sold fresh in their shells. They are very often eaten raw, requiring rapid turnover so that quality, especially bacterial quality, remains high. Some are cooked in apple fritters or as stuffed oysters, but this is the exception (mainly in restaurants), and cooked specialties are not very popular. Nearly half of the production is sold during the Christmas holidays and for New Year's. Mechanized structures are used, and larger firms have high daily preparations (20 ton/d) and sale.

\section{F. CONSTRAINTS}

\section{Diseases and Parasites}

From 1966 to 1969 , the Portuguese oysters C. angulata were damaged by the "gill disease". The local lesions were first attributed to a protist. Research on viruses in bivalves is recent. It was only in 1972 that Farley et al. ${ }^{68}$ found a virus in C. virginica (Gmelin). Comps and Duthoit ${ }^{69}$ isolated viral particles in gill lesions that caused a mortality rate of nearly $40 \%$ for the Portuguese oyster in France. The description of this virus placed it in the group of iridoviruses.

The second disease which affected the cupped oyster from 1970 to 1973, destroying the culture of Portuguese oyster in Portugal, Spain, France, and Great Britain, ${ }^{70}$ was due to another iridovirus (photo) causing a viral hemocytic infection. 
The introduced $C$. gigas was resistant to the two iridoviruses that lad destroyed the Portuguese oyster, signifying the specificity of the agent on the host. Mcanwhile, during some summer mortalities in 1977 in Arcachon Bay, the same virus as that of the angulata oyster was found on the Japanese oyster, ${ }^{71}$ which showed that the resistance of gigas oyster to iridovirus is not perfect.

The contanination of $C$. gigas by Mytilicola orientalis is recent. His ${ }^{22}$ found that this copepod was present in the digestive tract of 10 to $40 \%$ of the oysters, varying with the season. It can proliferate in the intestine (up to 40 individuals), building an intestinal occlusion and damaging cellular walls of the digestive tube..$^{73}$ An infection of more than three female oysters caused a significant reduction in the concentration of glycogen and carbohydrates of the total flesh. ${ }^{74}$

The oldest epizooite which affected the flat oyster in France, the Netherlands, England, and Ireland occurred from 1920 to $1927 .{ }^{4}$ A noninfectious agent had been described, but Orton $^{75}$ found abnormal cellular figures which Grizel ${ }^{76}$ thinks was due to an intracellular parasite.

The largest mortalities which disrupted the production of the flat oyster in Europe began in 1968 in French Brittany. The disease spread progressively to different farming areas from 1973 to 1975 on the French Atlantic coast ${ }^{77}$ (except in the open seawater), and later, with transportation of parasitized French flat oysters, to Spain and the Netherlands. Marteilia refringens is a protozoan considered to be related to the Paramyxea and not to the Haplosparidia. ${ }^{78}$ This parasite and its cycle was first described by Comps ${ }^{79}$ and confirmed by Grizel et al. ${ }^{51}$ and Perkins. ${ }^{80}$ It develops in the digestive epithelium with an annual cycle. The infestation period occurs in summer, when the temperature of water is above $17^{\circ} \mathrm{C}$, but the development cycle of the parasite occurs when the temperature is above $12^{\circ} \mathrm{C}$ (Figure 10). ${ }^{76}$ Franc ${ }^{81}$ showed that the parasite could have a sexual phase. The pathogenic action of Marteilia could be due to the disaggregation of epithelial cells of the digestive diverticulum. The parasite has been found in $O$. edulis on the Mediterranean coast in the lagoon of Thau and in Morocco (Nador), in C. gigas (but only in young stages), ${ }^{82}$ and in Mytilus edulis Linnaeus and Mytilus galloprovincialis Lamarck, where it can have a complete cycle. ${ }^{43}$ Marteilia refringens is not associated with mortalities for these species.

When Marleilia began to decrease, new abnormal mortalities oecurred in flat oysters in 1979 due to Bonamia ostreae, a new protozoan parasite of blood cells ${ }^{52,84}$ It seemed to be the same parasite, often called "microcell" disease because of the size of the cells ( 2 to 3 $\mu \mathrm{m})$. The cycle of infestation has not yet been elucidated. Unlike Marteilia, Bonumia infestation can occur during the whole year.

This hemocytopathogenic parasite incluces gill ulceration with perforations, indentations, and injuries to the conjuctive tissue. Severe infections spread to the different centers of North and South Brittany oyster production in France. ${ }^{85}$ As a result of commercial transport activities, this disease now occurs in the entire flat oyster culture areas in Europe. It is present in Denmark, the Netherlands, ${ }^{86}$ England, Ireland, and Spain. ${ }^{87}$ The flat oysters of the Mediterranean coast are not contaminated, but in 1988, Bonamia-contaminated flat oysters were found on the French Mediterranean coast. If they are transported to the Atlantic coast, they become infected. Everywhere Bonamia is present, it causes heavy mortalities in $O$. edulis. As the spat is very little contaminated by Bonamia, and as the level of contamination is a function of age, in Brittany as in the Netherlands, cultivation is possible at low density in open waters, with fast growth ( 2 or 3 years) after an cradication of all the old oyster beds. Despite these precautions, Von Banning ${ }^{86}$ found that $B$. ostreae has the ability to survive in very low density oyster stocks.

The lesson which can be learned with the severe diseases that appeared during the last 20 years of oyster culture in European countries, mainly in France, is that it is necessary to limit the transport of living populations, particularly of mollusks between different coun- 


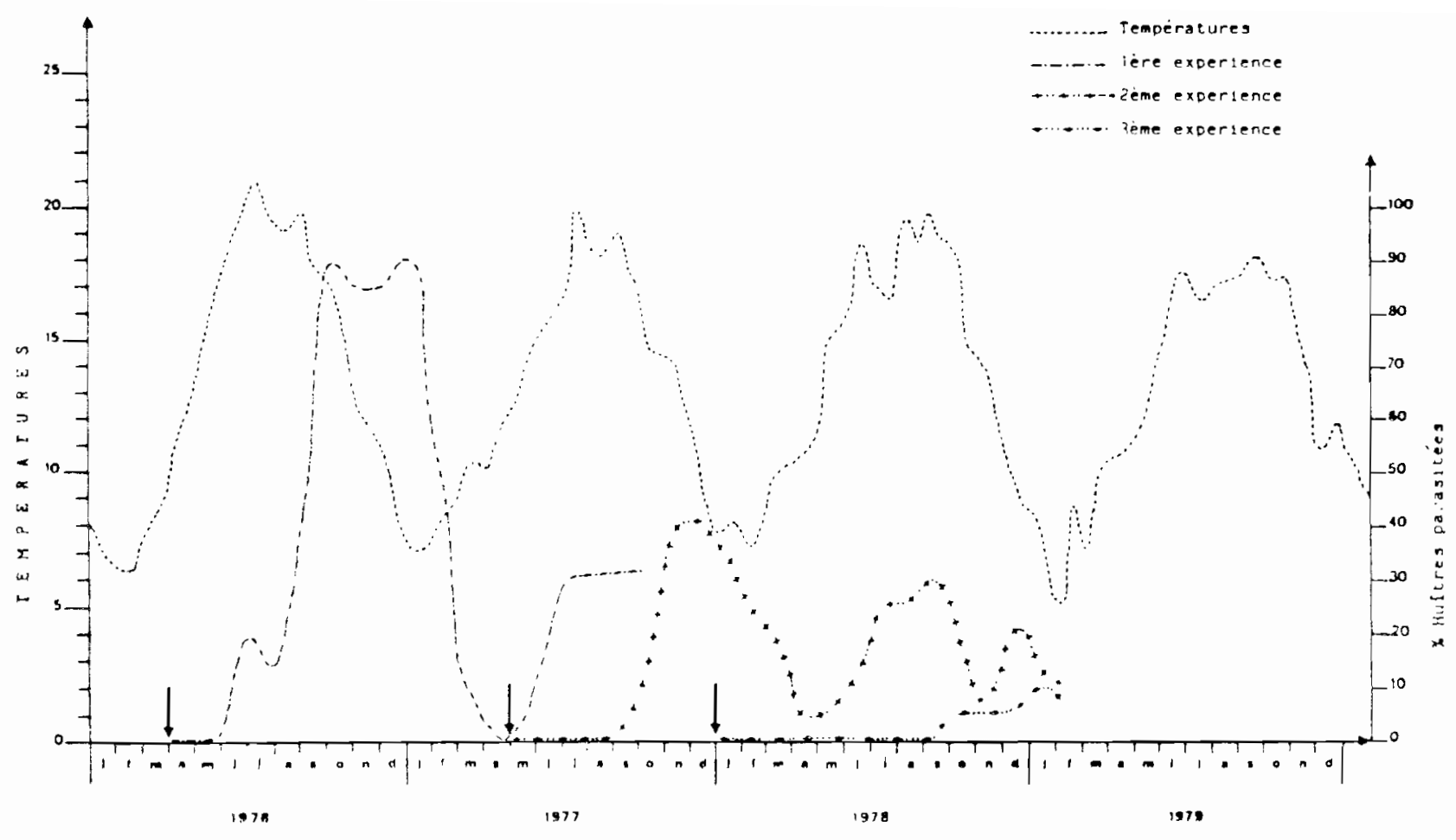

FIGURE 10. Evolution of the accurrence of Marteilia refringens in Ostrea edulis in relation to the temperature of the water. (From Grizel. H., Thêse d'Etal. Université des Sciences et Techniques du Languedoc, Montpellier, France, 1985. 145.) 
tries and in the same country between different bays. When for econonic reasons (lack of spat, importation of new races with better growth and resistance to disease) importation must take place, the risk of spreading diseases and parasites is very high. For these reasons, international organizations have made some recommendations. ${ }^{88}$ For example, ICES recommends that during introduction, broodstock should be kept in a closed systeni or quarantine with sterilized effluents. Only the progeny $\left(\mathrm{F}_{1}\right.$ or $\left.\mathrm{F}_{2}\right)$ can be introduced in the natural water. The ICES council also recommended procedures for current commercial practice involving quarantine and disinfection to confirm freedom from pests and discases.

\section{Predators and Competitors}

The predators are not very numerous; the most active is the green crab Carcinus maenas Linnacus, which eats large quantities of young spat on the collectors. Birds can cause serious predation (as ducks do for mussels in Wadden sea), but for oysters the populations of "huitres pies" (oyster pies) are not large. Some 10 years ago, the oystermen protected the oysters planted on the bottom by erecting pieces of iron to avoid the large flatfish (teyre), but these have actually become very rare. In the open sea, the density of starfish can be controlled by dredging.

Competitors can be very numerous, particularly if we speak about trophic competition. It is thought that large populations of cockles, clams, and mussels, consuming the same type of food, can affect the growth of the oysters. Crepidula fornicata (1 innaeus), imported in Europe from the U.S. during World War II, is the more active trophic competitor. Even though the energy budget of this species ${ }^{89.90}$ is four times less than that of the Japanese oyster, the very large biomass obliges the oystermen to dredge and destroy them.

The competition for space, particularly on the collectors for cultivated populations and on the rocks for natural oyster beds, is mainly between cirripeds and postlarva oysters during the month before and after settlement. During later stages of the culture, it is mussels and, again, Crepidula that attach to the shells of the oysters, sometimes completely covering them, forcing the oystermen to clean the oysters and the structures. Fouling is abundant on the Mediterranean coast where suspension culture techniques are employed. The main active species involved in this fouling are the Ascidians with active metabolisms. ${ }^{91}$ They are competitors both for a place on the substrate and from a nutritional point of view. 'The only remedy available is to raise the oyster structures out of the water and allow them to dry for several days. The constraints caused by predators and competitors are dealt with quite well by the oystermen and are not a limit to the development of the culture as diseases or pollution can be.

\section{Pollution}

The sedentary character of bivalves makes them sensitive to natural or induced disturbances of the environment. Their filter-feeding characteristics make shellfish vulnerable to bacteriological and chemical pollution. As oysters are cultivated on the coast and particularly near estuaries, they are sensitive to any modification of the eeosystems by pollution. Culture areas are in conflict because of different uses for the water in the region. Conflicts over the use and the quality of the input of freshwater will perhaps be the main problems in European countries in the future. One difficulty in maintaining the trophic level of cultivated bays is the changing quantity and quality of the estuarine water with the use of fertilization and development of irrigation. On the seashore, conflicts for space between tourism and oyster culture occur. Tourism also brings pollution problems (bacterial quality of the water, products used by pleasure craft, and so on). Antifouling paints, used on sailboats for destroying fouling species which grow on the boat bottons, use copper oxide, arsenic, and mercury salts. For the last 10 years, tributyltin (TBT) has been used. His and Robert ${ }^{92}$ and Robert and $\mathrm{His}^{93}$ have shown that the paints are severely toxic, particularly for the larval devclopment 


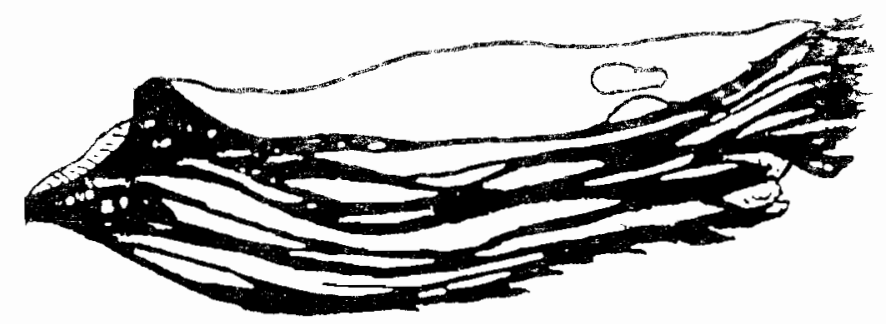

ITGURE 11. Transverse section of the upper shell of Crassostrea gigas showing abnormal growth in thickening with inhibition in length caused by TBT. (From Alzieu, C. and Héral, M., Ecotoxicological Testing for the Marine Environment. State University of Ghent and Inst. Mar. Sci. Res., Brcdene, Belgium, 1983, 187.)

of the Japanese oyster. Also, this product at very low levels stopped the growth of certain species of phytoplankton (Chaetoceros calcitrans Takano, Isochrysis galbana [Parke]) which can be used by oyster larvae as food. ${ }^{25}$ During the years 1977 to 1981 , no settlement occurred in the Bay of Arcachon with the development of pleasure crafts. When the use of TBT was regulated (1982), high levels of spat attachment occurred again. It has been shown that this product causes a malformation of the shell of the Japanese oyster. modifying calcification, inducing growth in thickness, and inhibiting the growth of the shell in length. ${ }^{94-98}$ Subsequently, the use of this type of paint was prohibited in 1982 on boats less than $25 \mathrm{~m}$ in France, and some years after in England and Germany. Thus, a product used for a concurrent activity can cause a severe disturbance of the production of oysters by acting on the larva, on its food, and on the growth of the shell. ${ }^{99}$

Another pollutant that cost quite of lot of money for the flat oyster culture in Brittany was the stranding of oil tankers near bays where cultivation of flat oysters was the main activity. Destruction of the oysters on the bottom occurred, and the remaining oysters could not be sold because they had directly absorbed the dissolved hydrocarbon, giving a horrible taste to the oysters. They could not be used for human consumption because of the toxic effect of these compounds. An evaluation of the consequences of the Amoco Cadiz stranding ${ }^{100}$ for oyster cultures has been estimated in 1980 to be 114 million francs. It is important but less so than the two diseases (Marteilia and Bonamia) which caused a loss of 1.6 billion francs in turnover and 1.3 billion francs of added value. ${ }^{101}$

\section{Other Constraints}

For these enryhaline species, the freshets are not a large constraint. Froin the market point of vicw, the taste of the oysters changes with freshwater, causing a decrease in sales. Until now, the lack of seed has not been a problem for the oyster culture. When there is no pollution, recruitment remains high. Héral et al. ${ }^{21}$ showed that the Portuguese oyster has becn without settlement only 2 years during the last century. For the Japanese oyster, 3 years without high settlement occurred during the last 15 years. It seemed to be due to the higher temperature requirements of these oysters and their need for a temperature above $18^{\circ} \mathrm{C}$ for larval development. If climate conditions remain cold, European countries could find hatcheries useful to remedy the deficiency of natural settlement.

A new constraint has been developing for European countries during the last 10 years in relation to summer phytoplankton blooms producing toxins. Paralytic shellfish poisoning (PSP) is associated mainly with the species Gonyaulax tamarensis Lebour or G. excavata Bolech. It has been described in the U.K. ${ }^{102}$ Norway, ${ }^{103}$ Spain, ${ }^{114}$ and Portugal. ${ }^{105}$ Diarrhetic shellfish poisoning (DSP) is found in association with Dinophysis acuminata Claparède and Lachman and perhaps with some other species of Dinophysis and Prorocentrum. ${ }^{106}$ PSP is 
present in France, ${ }^{107}$ the Netherlands, ${ }^{108}$ Ireland, ${ }^{109}$ and Spain. ${ }^{104}$ Oysters are less sensitive to toxin than nussels and clams. For these reasons, monitoring, based on "mussel watch", is followed in several countries.

High mortalities, with no toxicity for human consumption, have occurred on the Mediterranean coast due to an anoxic environment. This happened in the Thau lagoon in 1975 and 1986, in conjunction with several phenomena such as high temperature, no wind, stratification of the water, and high density of organic matter, causing dystrophic crises with red water. A bloom of photosynthetic sulfide-oxidizing bacteria produced hydrogen sulfide in anaerobiosis. ${ }^{101}$

In European countries, the technical problems do not present as major constraints, such as lack of facilities and transportation. Also, economic problems arise in supply and demand and the cost of production.

\section{G. MANAGEMENT}

In France, permits to harvest are given by the public authority that leases the culture grounds in the coastal areas. It is for a period of 30 years and varies in other countries. The concession is transmissible to the same familial enterprise. The yearly cost is about 200 French francs per hectare. The regulations for exploitation of the grounds are fixed by the state for the type of culture and the nature of the installation, as well as densities and the time of harvesting during the year. The state and the local agencies manage the bays by dredging (mud, sand, or parasites). Each oyster farmer is responsible for the management of his own grants.

The organization of the sanitary and quality control is very different and not yet unified between the different European countries. Sanitary control of mollusks in France is based on the assumption that it is more effective to prevent contamination than to try to remedy its effect. It is the reason why emphasis is placed on monitoring the water quality in cultivated zones. The coast line is classified into sanitary and unsanitary sectors, based on criteria of the number of fecal coliforms in oysters, mussels, or clams (Figure 12). In cases where an area is classified as unsanitary, harvest is, in general, forbidden. It may be allowed in certain cases, but the mollusks must be relaid in clean waters for at least one month or depurated by chlorine or ozone. In cases where the water is of good bacterial quality before sale, the cultivated mollusk must stay for 2 to $3 \mathrm{~d}$ before shipment in a "degorgeoir". It is a large tank (50 to $100 \mathrm{~m}^{2}$ or larger) where oysters or mussels stay in clean controiled seawater for self-depuration. ${ }^{11}$

In Holland and England, the sanitary regulation is based on the same regulations as in France. In Spain and Italy, all harvested mollusks are treated in depuration stations where water is disinfected with chlorine or ozone. The shellfish stay between 1 and $4 \mathrm{~d}$ in the depuration system in depending on the level of contamination. The European countries followed the recommendations of the International Code of Practice for Molluscan Shellfish by FAO/OMS. ${ }^{122}$ The sanitary laws of each country are evolving quickly, taking into account the quality of the waters, dinoflagellates and their toxins, levels of chemical pollutants in the water, hydrocarbons, organic-halogenous substances, heavy metals, following the European Economic Community (EEC) recommendations. ${ }^{113}$ As for the water, the different countries belonging to the European community will have to unify their regulations for the sanitary quality of the products before 1992 .

\section{RESEARCH AND DEVELOPMENT}

\section{A. INTRODUCTION}

Past success of molluscan culture has been due to natural spat settlement, the use of a natural phytoplanktonic free food, the large adaptation of sedentary species to the variation of the environment, and acknowledgment of cultivation techniques. 


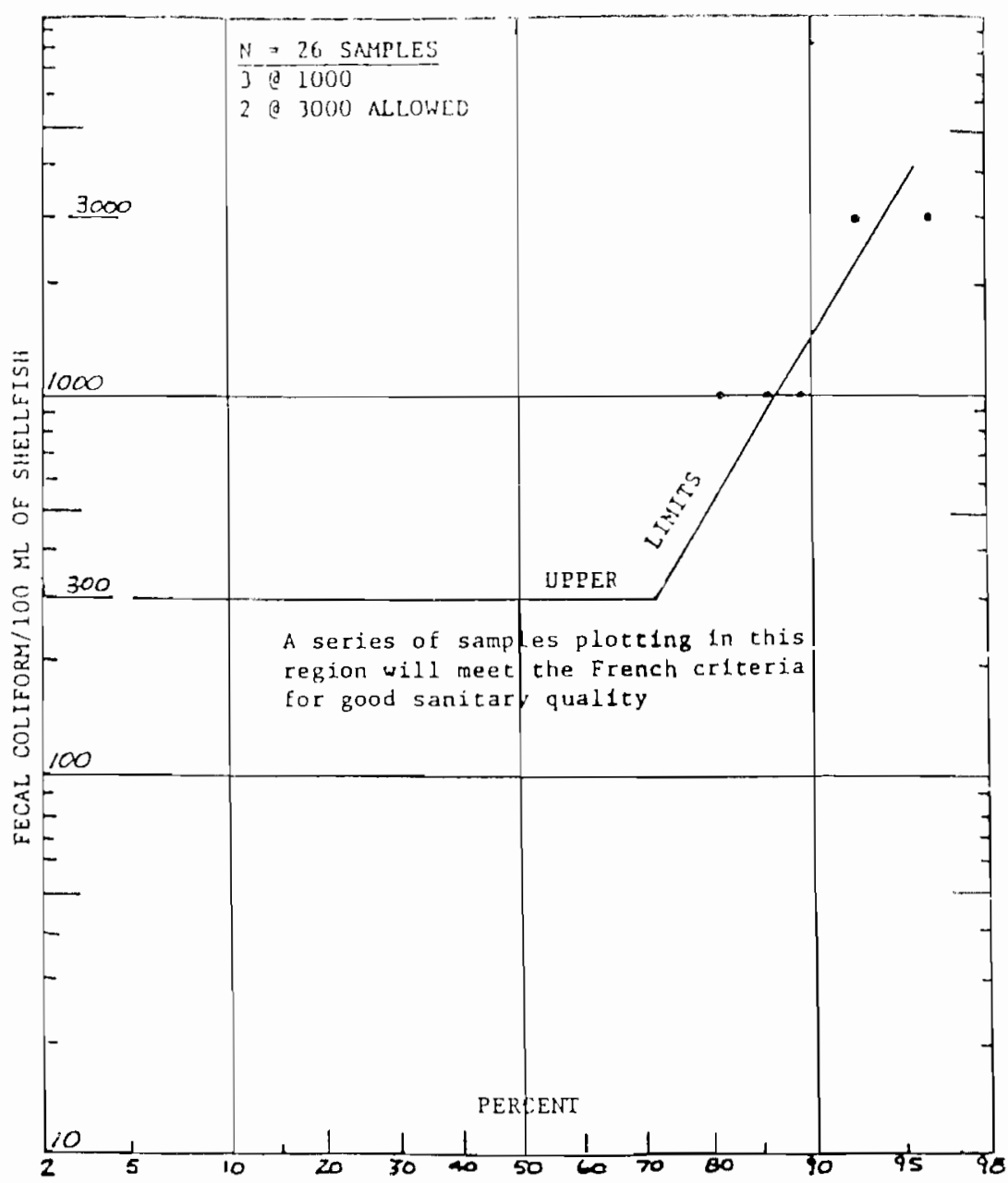

FIGURE I2. Criteria for classifying a culture site as sanitary. (From U.S. Food and Drug Administration and Sanitary Control of Shellfish in France, Washington, D.C.)

In spite of these opportunities and economic successes, there remain problems in maintaining the same level of productivity for countries where the cultures have reached a high level of production and in developing the potential of culture for other countries. Scientific research can resolve some of these problems, particularly new techniques of open-sea culture, prevention and determination of epizootic diseases, determination of the carrying capacity of the environment for cultivation of mollusks, prevention of degradation of the quality of the cultivated waters, prediction of dinoflagellate blooms, and selection by genetic manipulation of species with resistance to disease or better growth performance.

\section{B. TECHNIQUES AND CULTURE}

Theoretical research is being performed by French scientists and specialists to test the resistance of materials to find better subsurface long-lines that can resist storms (Figure 13). Structures on the botton at a depth of $20 \mathrm{~m}$ are tested for their suitability as nurseries of the young spat of $O$. edulis that settle on collectors fixed on long-lines. Each year different private companies test, with the help of research organizations, new materials for oyster culture to obtain efficient results. New types of plastic collectors, easier to transport, are used to obtain cultchless oysters. New vehicles for intertidal areas are studied to increase 

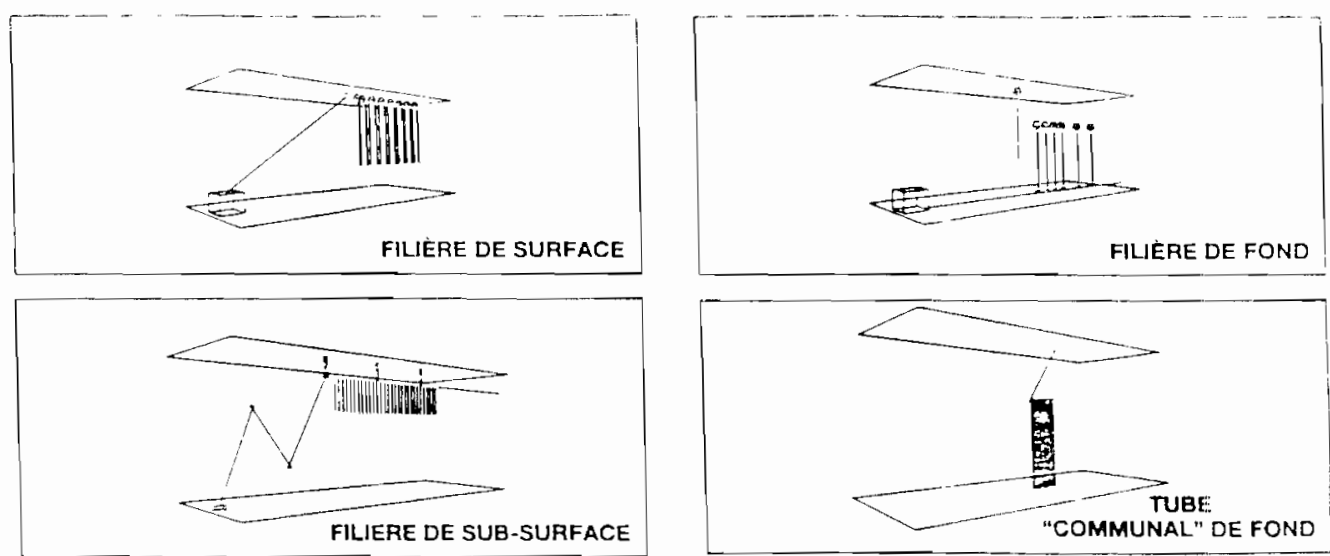

FIGURE 13. Description of different long-line techniques. (From Müller, et al., Cultures Mar., 145, 4, 1987 With permission.)
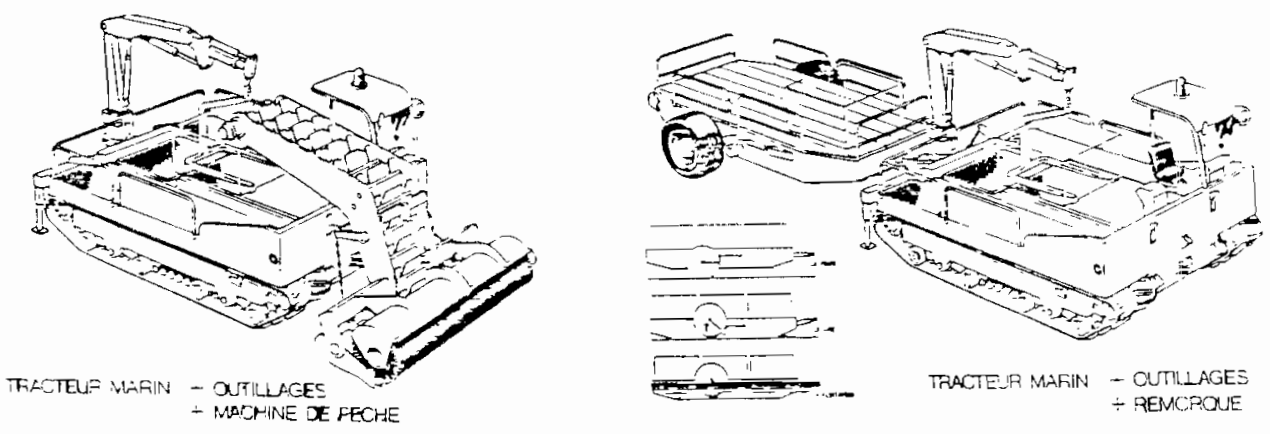

FIGURE 14. New vehicles for cultivation of oysters and mussels. (From Priour, Equinoxe, 9, 23, 1986. With permission.)

the mechanization of the harvest and transport of oysters and to decrease the cost of production (Figure 14). ${ }^{15}$ Technical research has bcen done to optimize the final handling of sliellfish (washing, grading, packaging) prior to shipment. For example, private firms and public researchers are developing machines to sort oysters by recognizing dead oysters by sound and by image analysis.

\section{PATHOLOGY}

After the recent diseases of the Portuguese and flat oysters, different Europcan countries have strengthened their regulations concerning mollusk importation. The quarantine recommended by ICES is applied even to products coming from hatcheries. Only if the spat are frce of disease can they be imported.

To increase the control of parasitized oysters, new techniques for diagnosis have been worked out. The techniques of monoclonal antibodies have been developed for the first time in mollusk pathology. ${ }^{16}$ The purification protocol achieved for Bonamia ostreae, a parasite of $O$. edulis, is described in Figure 15. The application of these techniques for Bonamia ostreae was described by Boulo et al. ${ }^{118}$ From 700 hybridomas, eight were selected for their Bonamia-specific antibody reaction. Two were retained to make Bonamia diagnosis by indirect immunofluorescence. This new technique, along with the use of the commercialized enzyme-linked immunosorbent assay (ELISA) test, is significantly less time-consuming than the traditional histological preparations. Therefore, the number of examinations will be 


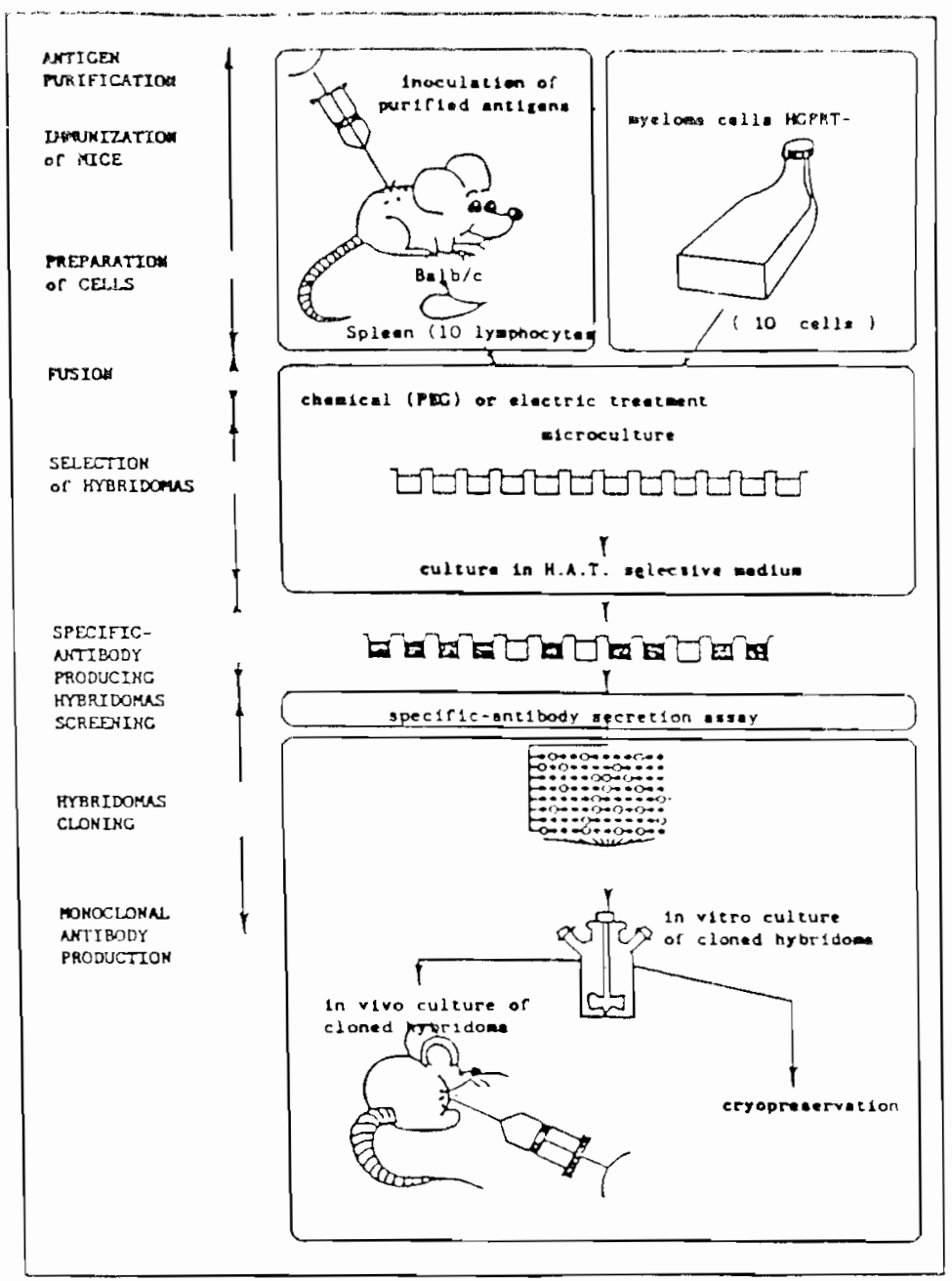

FIGURE 15. General principle of hybridona technology. (From Mialhe, E., Boulo. E., Grizel, H., Rogier, H., and Paolucci, F., Disease Processes in Marine Bivalue Molluscs. American Fisheries Society, Spee. Publ. Ser., in press. With permission.)

larger, allowing for a better zoosanitary survey, and precise determination of the rate of infection to be possible.

\section{CARRYING CAPACITY OF THE ENVIRONMENT}

Two models have been used to estimate the carrying capacity of a body of water. The first is based on the molluscan harvest and the second on the tropic relationships. The first model uses the hypothesis that the environment is constant or its fluctuation oscillates around the same mean. The data which are necessary for the construction of the model are the growth rate of the cultivated mollusk, the survival rate, and the estimation of the total cultivated biomass.

Some sampling strategies have been developed to obtain these data. The more difficult one is to estimate the reared stocks precisely. ${ }^{13}$ The method includes taking aerial photographs of the intertidal cultivated area and estimating the density based on subsampling in the field. Aerial photographs all over the bay measure the areas effectively. They are analyzed, either extensively for small bays or by a systematic sampling for larger areas, 


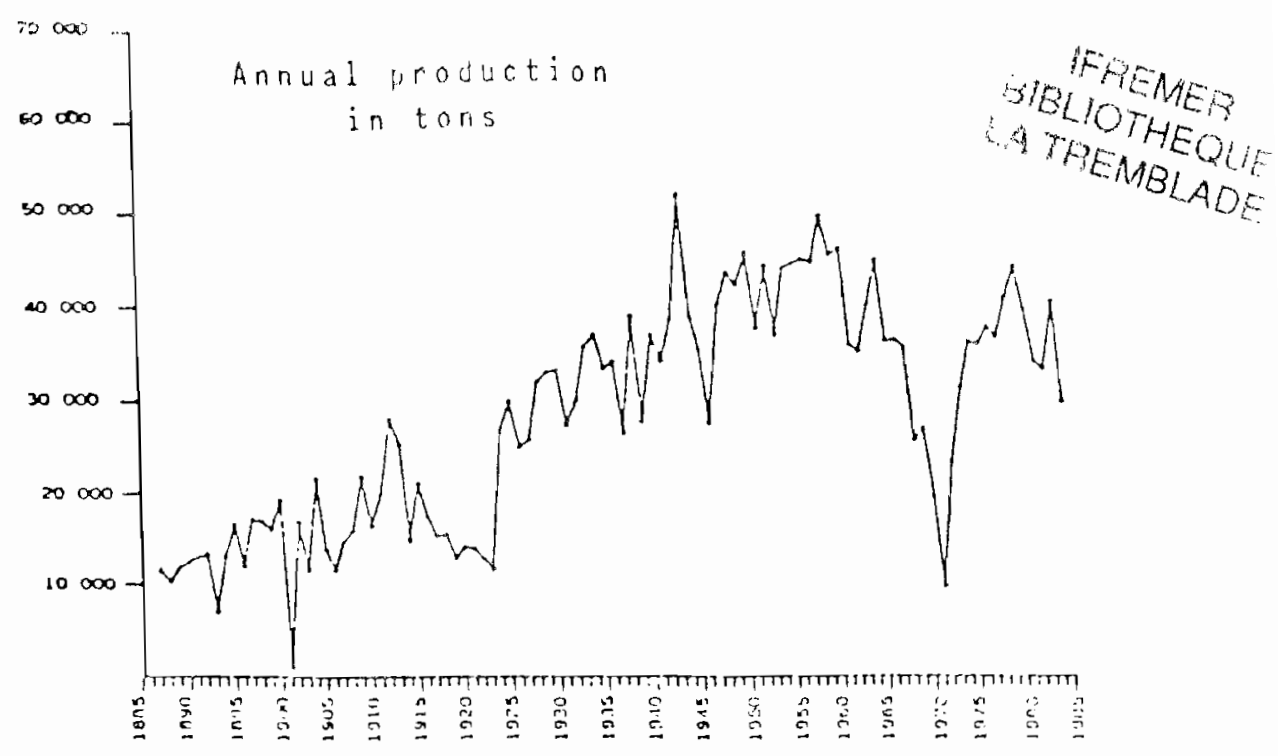

FIGURE 16. Evolution of the annual production of adult oysters grown in the bay of MarénnesOléron. ${ }^{\text {is }}$

with a precision of $3 \%$. Research is going on with remote sensing ${ }^{120}$ and with numcrical signals obtained with a CCD video camera to optimize the cost and the performances.

Estimations of local biomasses are obtained by a random subsampling in different strata according to the modes of cultivation and the geographic areas. The stocks are computed as the product of biomass and cultivated surfaces, with a total precision of about $6 \%$. This approach has been used since 1984 in the main large bays producing oysters along the French coast. It is only after gathering data on stocks, growth performance, and mortality rate over a long period, with a large spectrum of variation, that a precise dynamic model will be built. A model has been achieved with historical data. ${ }^{6.38}$ The Bay of Marénnes-Oléron was chosen because it is the main European basin for oyster production and has had a large decrease in its growth performance. The evolution of the production of the cupped oyster is estimated for the last century (1885 to 1985) from three different sources of data in Figure 16.

The growth rate and the mortality rate of the population of oysters presented an increase of the duration to obtain adult oysters while the survival rate is decreasing (Figure 17).

The total biomass in culture is calculated from annual production and the yield of culture. growth, and mortality (Figure 18). This simulation of the biomass gave results that are on the same order as those achieved by sampling over the last 3 years.

The relation between the stock function of the production showed clearly a maximun plateau of 40,000 ton. This limited corresponded to the maximum production capacity of the ecosystem limited by the trophic capacities of the bay. The maximal production of the bay could be modeled by an equation of the same nature as the one used for the growth of the populations. So, the Von Bertalanffy equation $P=P_{\max }\left(1-e^{-K B}\right)$ fits well with the data $\left(\mathrm{P}_{\max }\right.$ is the maximum production of the Bay of Marénnes-Oléron, with $\mathrm{B}$ the cultivated stock; for $C$. angulata $\mathrm{K}=0.026$ and $\mathrm{P}_{\text {nux }}=41,873$ ton; for $C$. gigas $\mathrm{K}=0.028$ and $\mathrm{P}_{\max }=52,450$ ton $)$. The yield production on the stock $(\mathrm{P} / \mathrm{B})$ in relation to the stock followed a negative exponential curve as the evolution of the annual growth rate in relation to the stock (Figure 5).

The maximum production of 40,000 ton could be reached with a stock of Portuguese oysters of 130,000 ton and with a stock of Japanese oysters of 80,000 ton. This diflerence between the two species can be explained by the energetic demands of each oyster. For the 


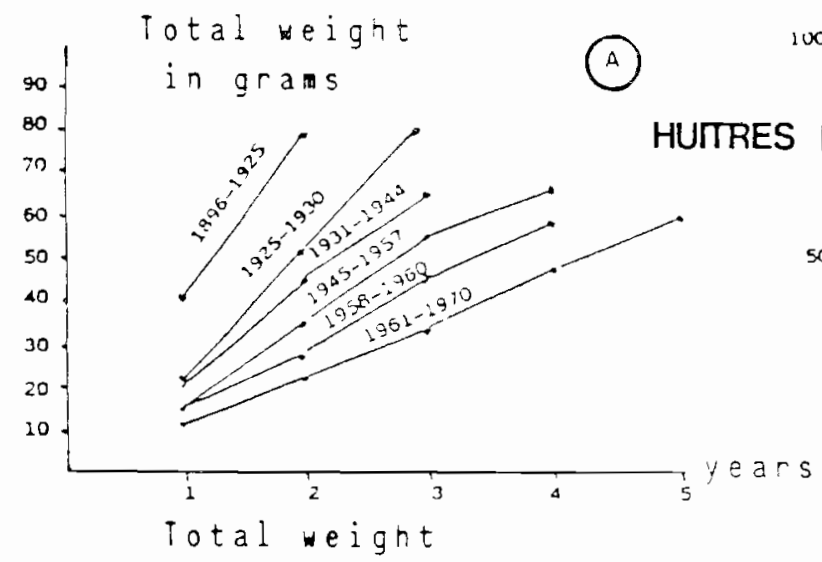

$100 \%$ of sLrviva]

(c)
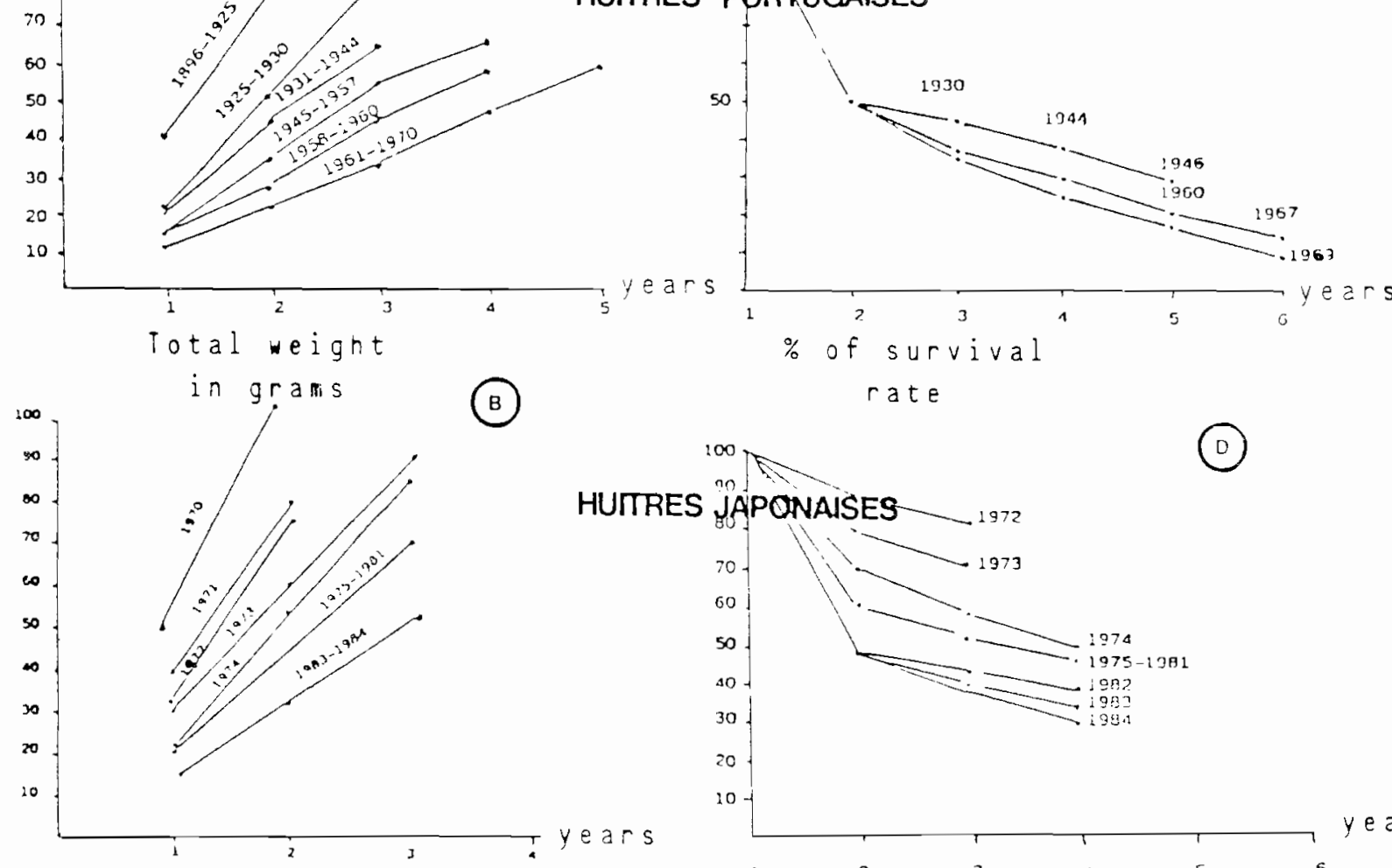

ב'

FIGURE 17. Evolution of the time necessary to obtañ adult oysters: (A) Poriguese oystel. (B) Japanese uvster Survival rate after the îrst breeding year: (C) Portuguese oyster, (D) Japanese oyster ${ }^{38}$ 


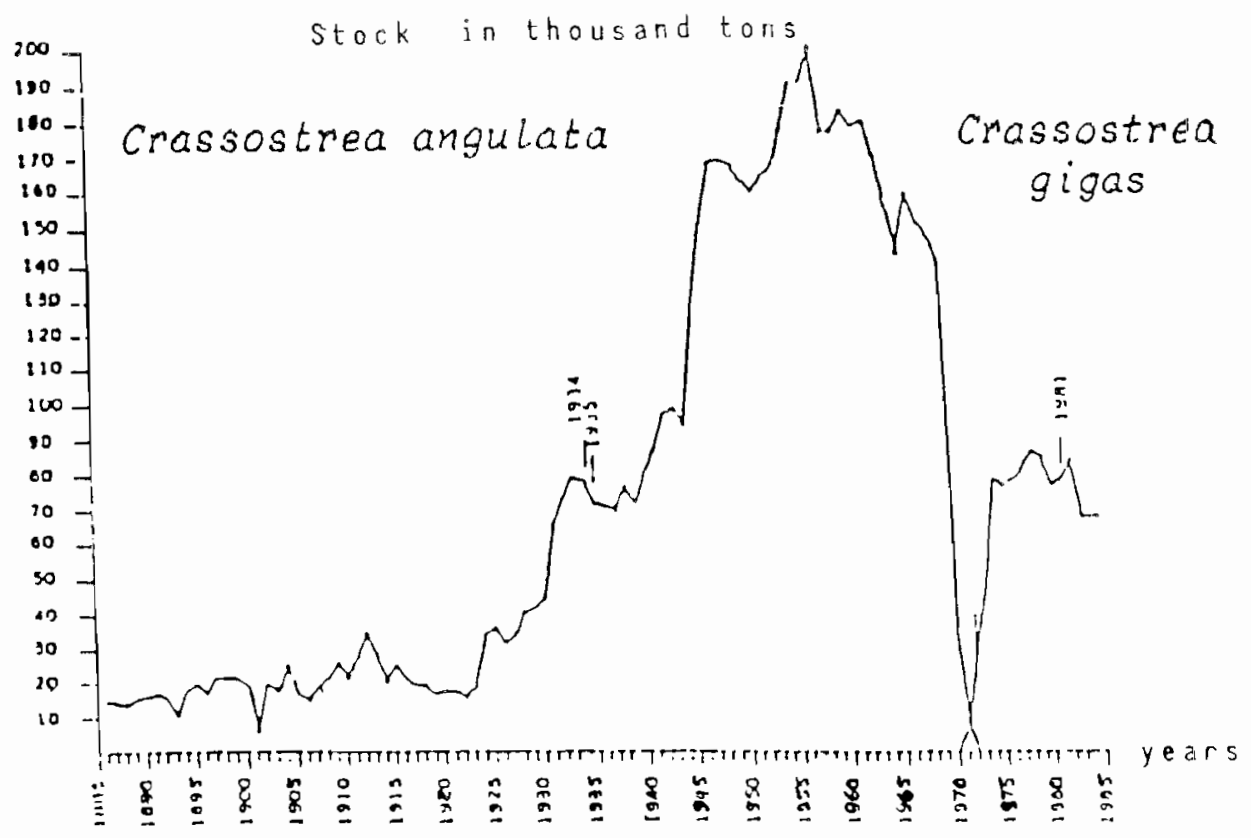

FIGURE 18. Calculated evolution of the total biomass of cultivated oysters in the bay of Marénnes-Oléron. (From Héral, M., Deslous-Paoli, J. M., and Prou, J., ICES, Mariculture Committee, F, 41, 22, 1986. With permission.)

same weight, the assimilation of food by the Japanese oyster is 1.7 times more than that of the Portuguese oyster. ${ }^{6}$ If the impact of these two oysters on the ecosystem is compared, this transformation coefficient must be taken into account. This model showed that without management of cultivated oysters, the stocks tended to exceed the minimal biomass necessary to reach the maximal potential of production. If stock regulation is applied, it gives oyster farmers the advantages of decreased duration of the breeding cycle and a decrease in chronic mortalities, which brings better profits to the enterprises.

The analytical model is based, on one hand, on the energy demands of oyster populations and, on the other hand, on the quantity of available food that is transported by the currents, obtained with a numerical physical model.

A general equation of the energy budget of oyster populations has been established following the equation $\mathrm{A}=\mathrm{P}+\mathrm{R}=\mathrm{C}-(\mathrm{F}+\mathrm{U})$, with $\mathrm{A}=$ assimilation, $\mathrm{R}=$ respiration, $\mathrm{F}=$ particular excretion (feces and pseudofeces), $\mathrm{U}=$ dissolved excretion, $\mathrm{C}$ $=$ consumption, and $\mathrm{P}=$ production $[\mathrm{P}=\mathrm{Pg}+\mathrm{Pr}+\mathrm{Ps}$, with $\mathrm{Pg}=$ production of the flesh, $\mathrm{Pr}=$ production used for the reproduction, $\mathrm{Ps}=$ production of the secretions (shell, mucus)]. A study on oyster reefs permits evaluation of the different components of the energy budgets of $\mathrm{I}$ - and 2-year populations. It appears that in the Bay of Marénnes-Oléron, the feces and pseudofeces represented $70 \%$ of the energy consumed (Figure 20), and the production of the flesh was $2.8 \%$ for the 1 -year-old oyster and only $0.2 \%$ for the 2 -yearold oyster. ${ }^{40,121.122}$ During the same period, the available food was followed during tidal cycles each month for a neap tide and a spring tide. These data permitted an individual growth model, taking into account the relations between respiration assimilation and the oyster weight, the temperature, the season and the particular available food (protein, lipid, carbohydrate) (Figure 21).

To calculate the level of the available food in the whole bay, an advection-dispersion model is used. As time and spatial scales have to be consistent with the chosen biological scale ( $1 \mathrm{~d}$ ), a box structure is applied to the oyster production area. The residual Lagrangian 


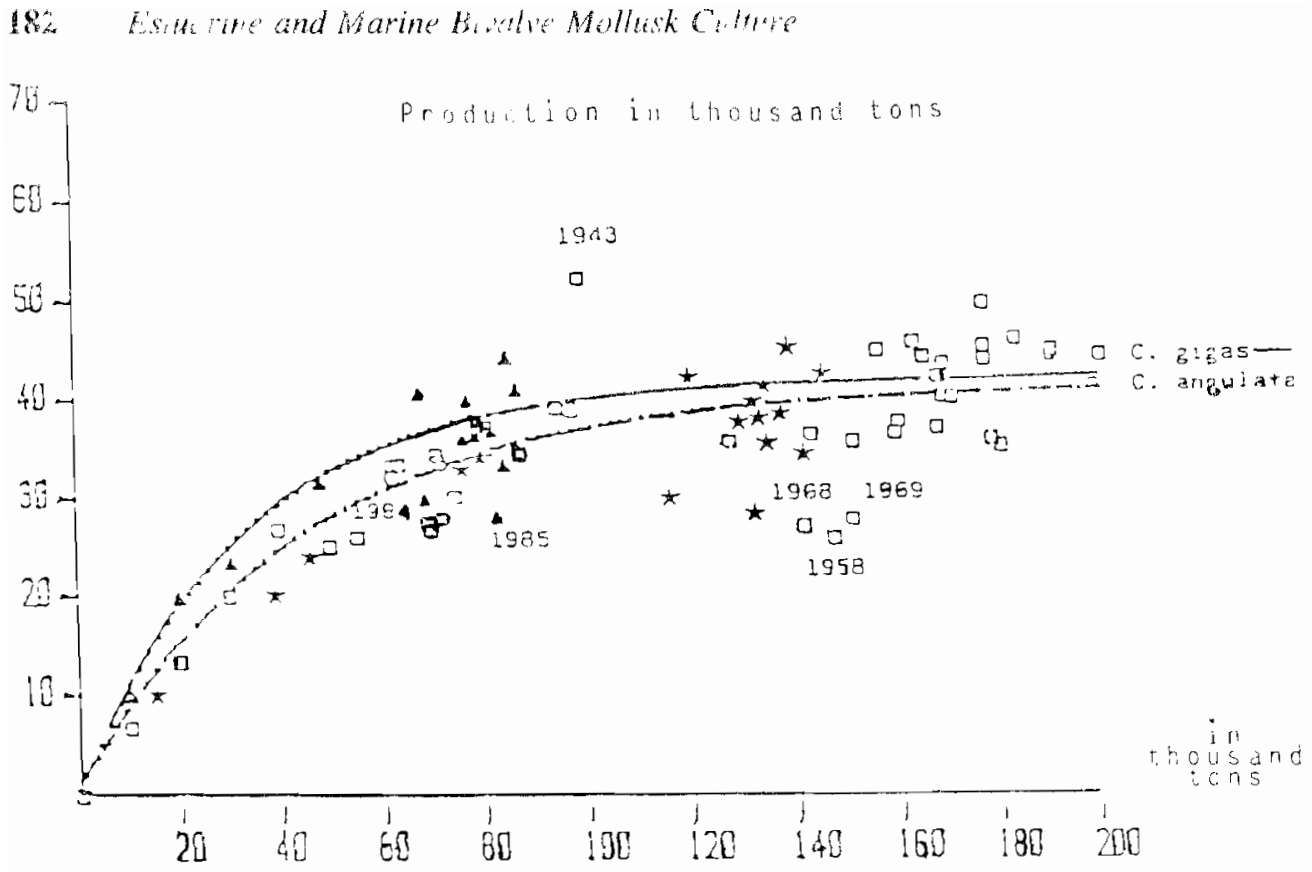

FIGURE 19. Evolution of the annual production of the stock in culture for Crassostrea angulata (L L), Crassostrea gigas ( $\mathbf{\Delta}$ ) and for Crassostrea gigas converted in equivalent Crassostrea angulata ( $\star$ ). (From Héral, M., DeslousPaoli, J. M., and Prou, J., ICES, Mariculture Committee, F, 41, 22, 1986. With permission.)

currents are calculated. The dispersion is a function of the transport and of the difference in concentration between adjacent boxes. ${ }^{128}$ The food is actually a driving variable and is injected at the three limits of the box model as the salinity with time series on 5 years, averaged to smooth the variability. The transport model is validated by the use of predicted salinity and observed salinity data in the middle of the bay (Figure 22).

The ecosystcm model is built with a stock of oysters of two ages in each box, and the growth model function of the food is transported by the physical model. The trophic molluscan shellfish competitors and their assimilation of food are introduced in each box as driving variables. This approach could permit fluctuations in the cultivated stocks of oysters and the ability to make predictions about the growth rate in the different areas. The comparison between the results of the global model (Figure 23B) and the simulation of the analytical model (Figure 23A) dcmonstrates the same cffects of the total cultivated biomass on the annual growth rate, but with more precision for the different areas with the analytical model.

This model uses, up to now, too many simple hypothescs, but it shows the research methods we need to have a useful tool for managenent. It dcmonstrates that a multidisciplinary approach among biologists, scientists, and sedimentologists could obtain a predictive evolution of the growth rate of the cultivated species as a function of the food and of all other factors, particularly pollution, that can modify the quality and the quantity of the trophic requirements.

It is evident that to be predictive it is necessary to go farther in the study of energy demands of the oysters for particular and dissolved substances. In another way, a phytoplanktonic model, which simulates the variations of the input of nutrients from the estuary, will be helpful for the study of the consequences of the use of freshwater on oystcr production.

\section{FUTURE DEVELOPMENTS}

A new step can be achieved in oyster culture with the development of genetic manipulation. Recently obtained triploids and tetraploids for $C$. gigas opened a new way. In 

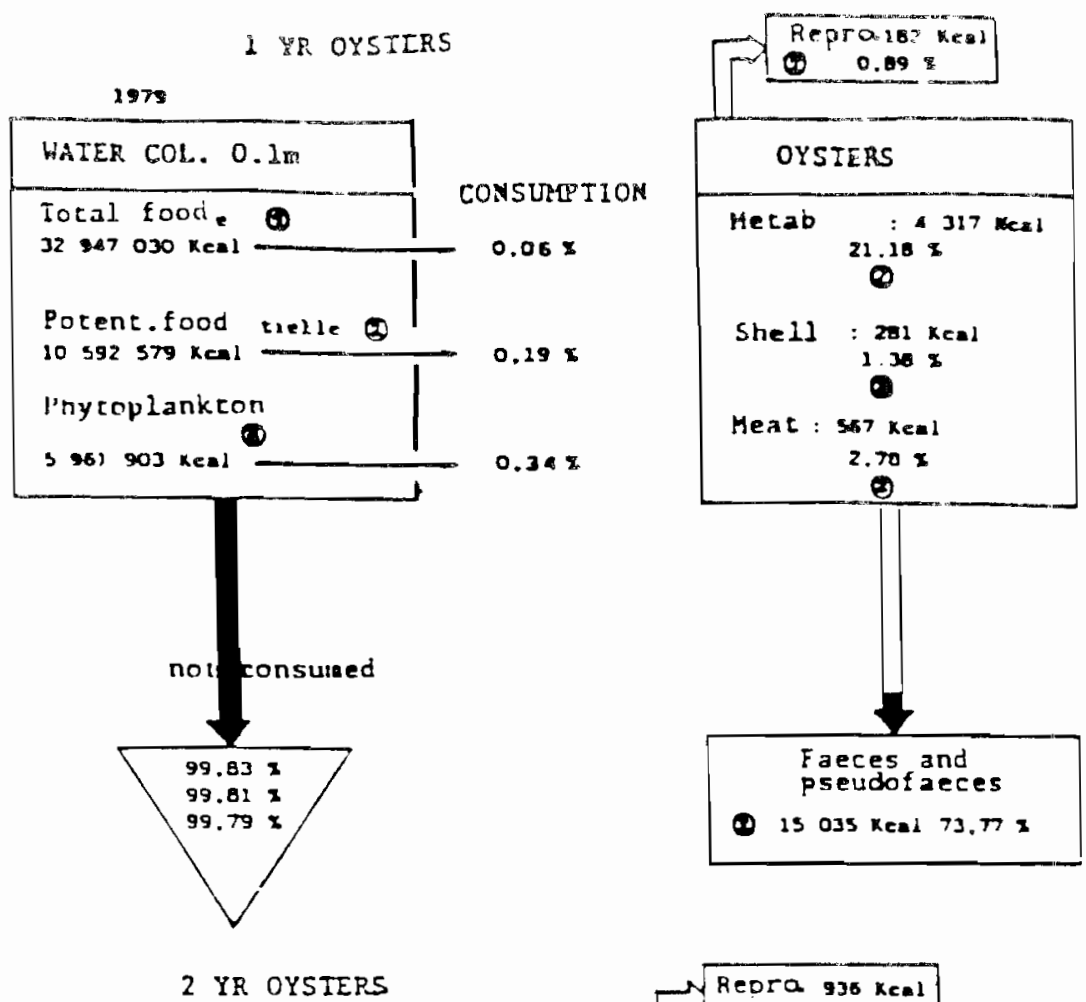

\section{0}
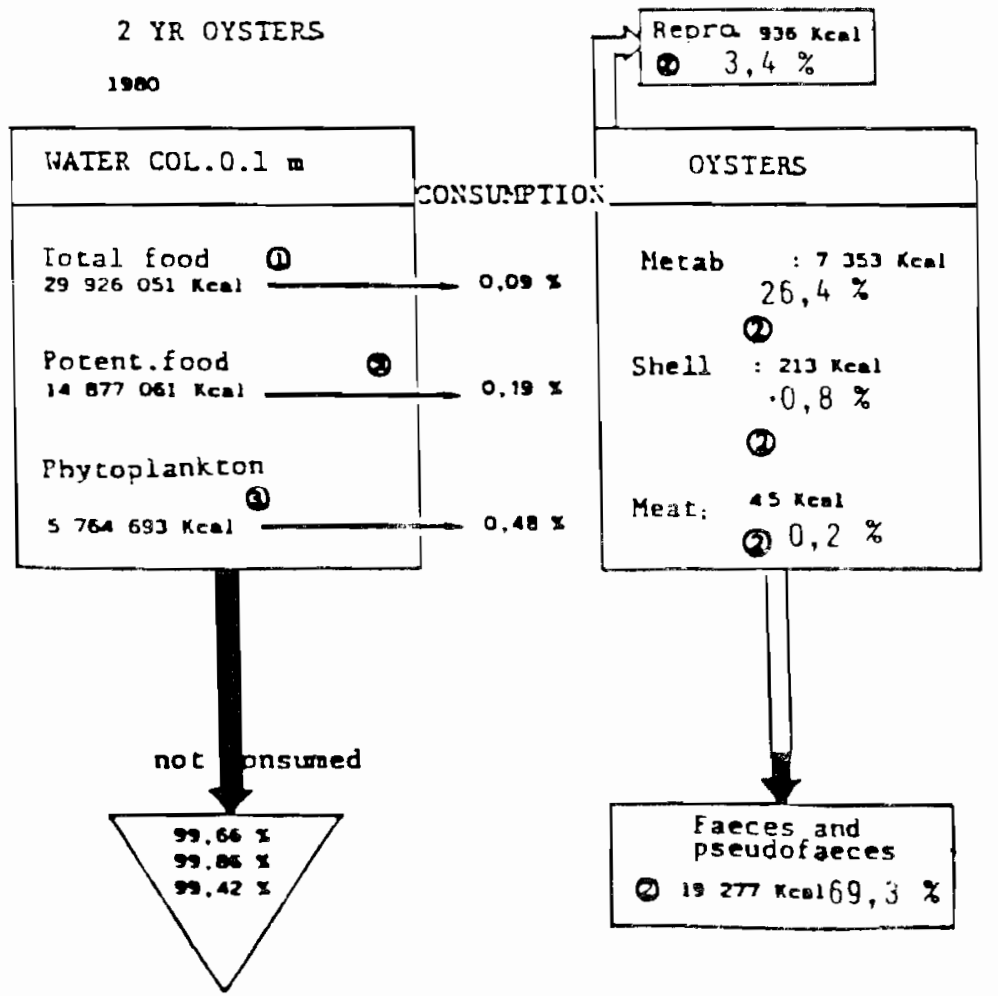

FIGURE 20. Annual energy flow between a $0.1-\mathrm{m}$ water column transmitting at a current of $0.3 \mathrm{~m} / \mathrm{s}$ and a population of grown oysters at a density of 200 individuals $/ \mathrm{m}^{2}$ (Héral et al. ${ }^{40}$ Delous-Paoli et Héral ${ }^{122}$ ) (From Héral. M.. el al, Oceanus, 9(3), 169, 1983; Deslous-Paoli, J. M., and Héral, M., Haliotis, 14, 79, 1984. With permission.) 
Kjoule

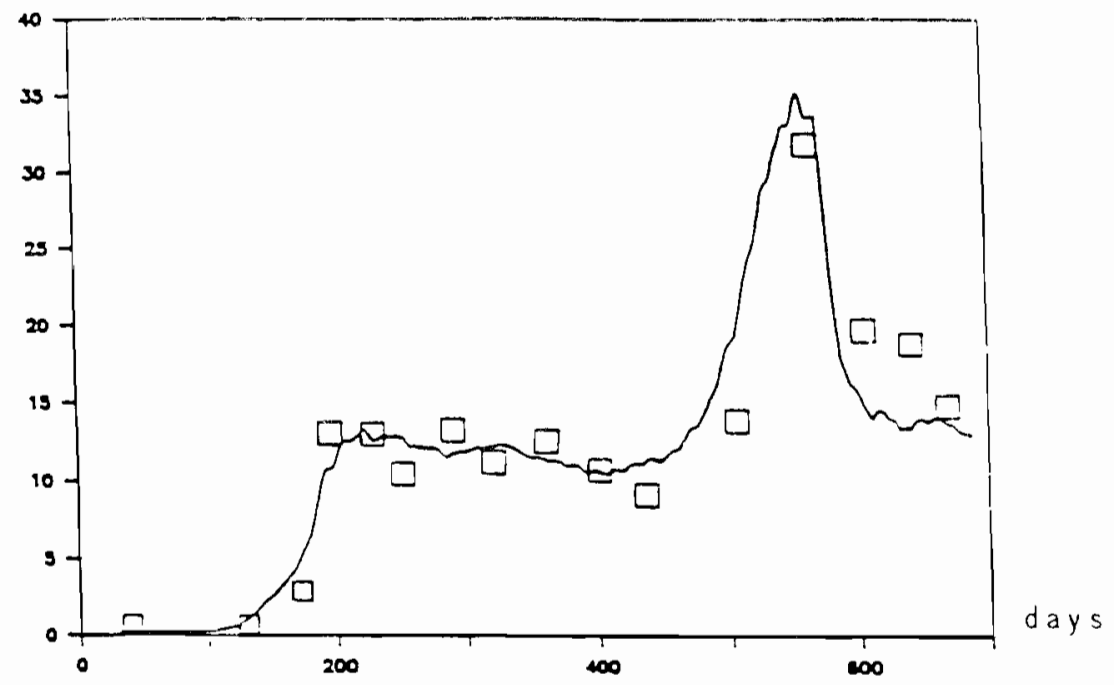

FIGURE 21. Simulation of the individual growth of oysters in the Marénnes-Oléron Bay expressed in $\mathrm{K}$ joule function of the assimilation and respiration $(\square$ ), observed data. (From Bacher, C., Rapp. IFREMER, 1987, 12.)

$S \%$

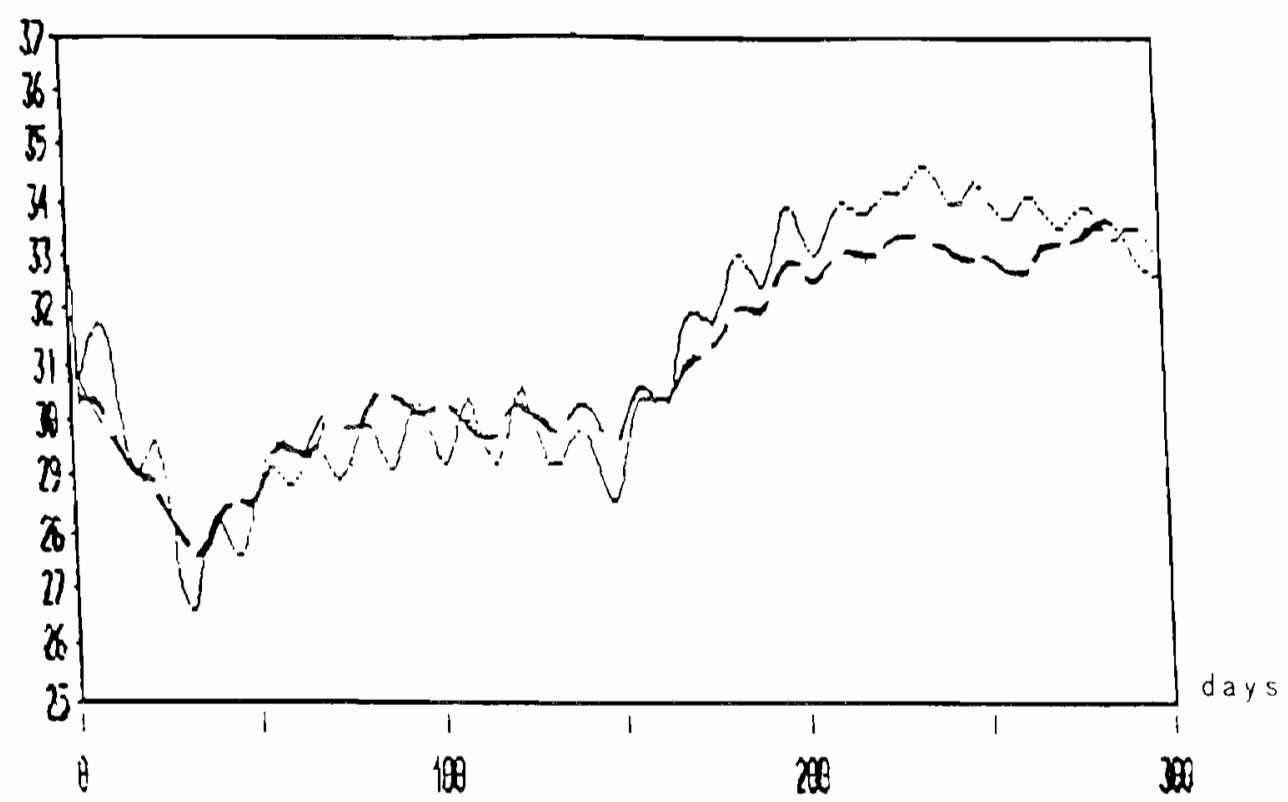

FIGURE 22. Observed salinity (--) and simulated salinity (--) calculated by the advection-dispersion model in the middle of the bay. (From Bacher, C., Rapp. IFREMER, 1987, 12.) 

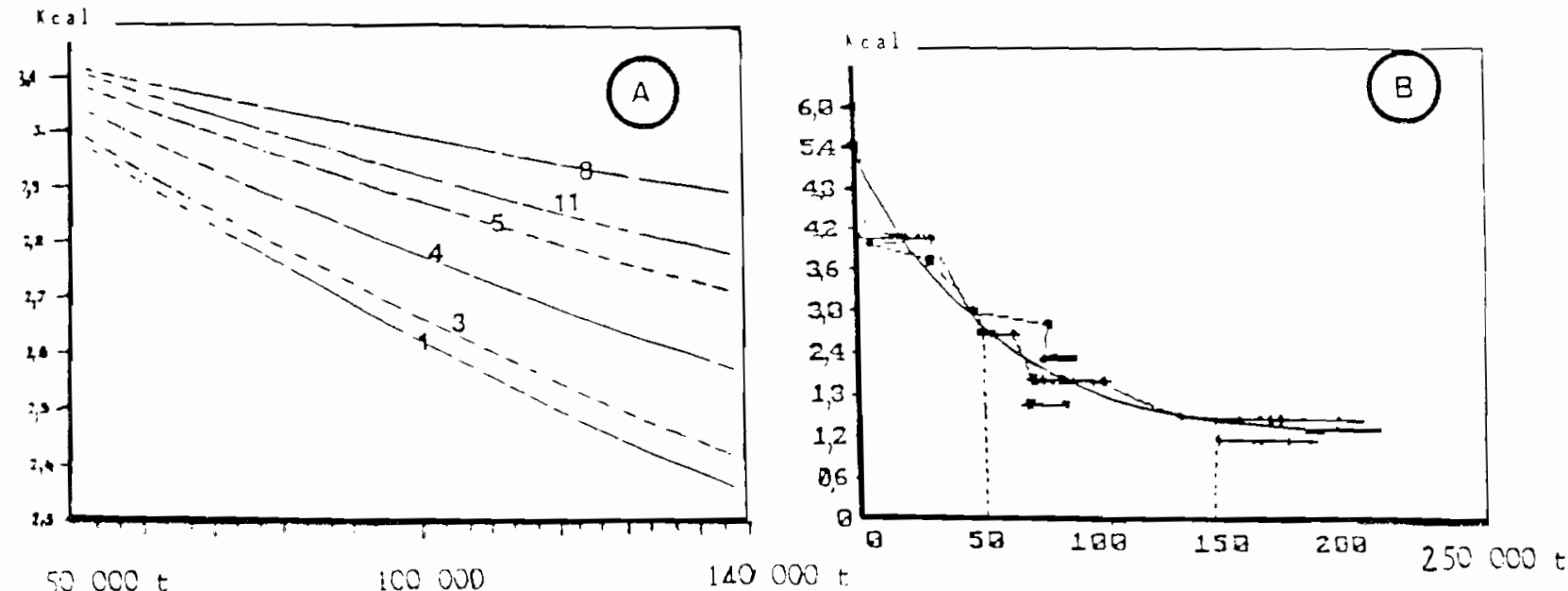

FIGURE 23. (A) Simulation of the evolution of the annual production results of the analytical model. (From Bacher, C., Rapp. IFREMER, 1987, 12.) (B) Evolution of the annual production of one oyster, results of the global model. (From Héral, M., Deslous-Paoli, J. M., and Prou, J., ICES, Mariculture Committee, F, 41, 22, 1986. With permission.) 
summer, these oysters are losing nore than half of their (dricd) body weight for reproduction. It would be advantageous to produce sterile oysters that devote less effort to the reproduction process. These chromosomal manipulations can be realized by thermal shocks, ${ }^{124}$ hydrostatic pressure, or with cytochalasin B. ${ }^{125}$ Energy for the reproduction could be used instead for somatic growth, providing an answer for the growth decrease observed in European closed bays in the summer. Hatchery-produced seed would be a means of regulation to avoid overstocking due to natural settlement, which is too numerous in relation to the density of collectors.

Another new promising sector of research for the oyster industry in European countries is the bioeconomic analysis of molluscan shelifish. Coupling models of dynamics of production with marketing systems could demonstrate not only the different scenarios that oyster farms can choose for their individual development, but also the interest of a group strategy that can be difficult to reconcile with the individual one. Gilly and Meuriot ${ }^{126}$ stated that "it is essential to involve disciplines such as sociology or political science in the study of the crucial elements affecting the dynamics of the shellfish sector of the economy," e.g., knowledge of the choices and strategies available to operators, either as individuals or groups; decision-making processes leading to arbitration of conflicts on use of space and the environment; and the role and conditions of using scientific information in these decision-making processes.

\section{REFERENCES}

1. Grassé, P., Traité de zoologie, in Mollusques Lamellibranches, Vol. 5, Masson, Paris, 1960, chap. 2.

2. Ranson, G., Les huîtres, biologie, culture, in Savoir en Histoire Naturelle, Vol. 23, Lechavalier, Paris, $1951,260$.

3. Ranson, G., Les espèces d'huîtres vivant actuellement dans le monde, définie par leurs coquilles larvaires ou prodissoconques. Etude des collections des grands musées d'histoite naturelle, Rev. Trav. Inst. Fechess Marit., 2(3), 128 and 205, 1967.

4. Menzel, R. N., Portuguese and Japanese oysters are the same species, J. Fish. Res. Board Canada, 31(4), $453,1974$.

5. Buroker, N. E., Hershberger, W. K., and Chew, K. K., Populations genetics of thc family ostraidae. I. Instraspecific studies of Crassostrea gigas and Saccostrea commercialis. II. Interspecific studies of the genera Crassostrea and Saccostrea, Mar. Biol., 54, 157 and 171, 1979.

6. Héral, M., Deslous-Paoli, J. M., and Prou, J., Dynamiques des productions et des bionasses des huîtres creuses cultivêes (Crassostrea angukata et Crassostrea gigas) dans le bassin de Marennes-Oléron depuis un siècle. ICES, Mariculture Committee, F, 41, 22, 1986.

7. His, E., Premiers éléments de comparaison entre l'huîtres protugaise et l'huître japonaise, Sci. Proches, Bull. Inst. Peches Marit., 219, ], 1972.

8. Bougrier, S., Gaguenes, G., Bachere, E., Tige, G., and Grizel, H., Essai de réimplantation de Crassostrea angulata en France: résistance au chambrage et comportement des hybrides $C$. angulata - $C$. gigas, ICES, Shellfish Commince, $K, 36,14,1986$.

9. Marteil, L., La conchyliculture françaisc. Vol. 2: Biologie de l'huître et de la moule, Rev. Trov. Inst. Peches Marit., 40(2), 149, 1976.

10. Combs, M., Recherches histologiques et cytologiques sur les infections intracellulaires des mollukques bivalves marins, Thèse d'Etat. Université des Sciences et Techniques du Languedoc, 1983. 128.

11. Korringa, P., Experiments and observations on swarming pelagic life and setting in the European flat oyster Ostrea edulis L., Arch. Necrl. Zool., 5, 249, 1941.

12. Héral, M., Deslous-Paoli, J. M., Razet, D., and Prou, J., Essajs de mises en évidence in siıu de paramètres biotiques et abiotiques de l'eau et de l'interface eau-sédiment intervenant dans la production de l'huître. Crassostrea gigas, Oceanus, 10(4), 465, 1984.

13. Deslous-Paoli, J. M., Héral, M., Goulletquer, P., Boromthanarat, W., Razet, D., Garnier, J., F"rou, J., and Barillet, L., Evolution saisonnière de la filtration de bivalves intertidaux dans des conditions naturelles, Oceanis, 13(4-5), 575, 1987.

14. Maurer, D., Comps, M., and His, E., Caraetéristiques des mortalités estivales de l'huître Crassostrea gigas dans le bassin d'Arcachon, Halionis, 15, 309, 1986 
15. Mori, K., Effects of artificial entrophisation on the metabolism of the Japanese oyster, Crassostrea gigas, Mar Bicl., 53, 361, 1979.

16. Perdue, J. A., Beattie, J. H., and Chew, K. K., Sone relationships between gametogenetic cycle and summer mortality phenomenon in the Pacific oyster (Crassostrea gigas) in Washington State, J. Shellfish Res., 1(1),9.1981

17. Neudecker, T., Condition index; and norphometric data of oyster (Crassostrea gigas) from the Geman Baltic coast, ICES, Mariculture Committee F, 9, 11, 1979.

18. Yonge, C. M., Oysters, Collins, London, 1950, 209.

19. Muranata, M. S. and Lannan, J. E., Broodstock management of Crassostrea gigas: environmental influences on broodstock conditioning, Aquaculture, 39, 217, 1984.

20. Mann, R., Some biochemical and physiological aspect of growth and gametogenesis in Crassostrea gigas and Ostrea edulis grown at sustained elevated temperature, J. Mar. Biol. Assoc. U.K., 59, 95, 1979.

21. Héral, M., Deslons-Paoli, J. M., and Prou, J., Influence due climat sur le recrutement et sur la production d'huitres cultivées (Crassostrea angulata et Crassostrea gigas) dans le bassin de Marénnes-Oléron (France). ICES, Mariculture Committee F, 40, 20, 1986.

22. Lubet, P. E., Influence des facteurs extemes sur la reproduction des mollusques lamellibranches, Oceanus, $6(5), 469,1980$

23. Imai, T., Hatanaka, M., Sato, R., Sakai, S., and Yuki, R., Artificial breeding of oysters $\Perp n$ tanks, Tohoku J. Agric. Res., 1, 69, 1950.

24. Loosanoff, V. L., Davis, H. C., and Chanley, P. E., Dimensions and shapes of larvae of some marine bivalve mollusks, Malacologia, 4(2), 351, 1966.

25. His, E. and Robert, R., Developpnent des véligères de Crassostrea gigans dans le bassin d"Archachon. Etudes sur les mortalités larvaires, Rev. Trav. Inst. Peches Marit., 47(1 and 2), 63, 1985.

26. Walne, P. R., Culture of bivalve molluscs, Fishing News (Bonks), West Byflect, 1974, 173.

27. Medcof, J. C., Oyster farming in the maritimes, Bull. Fish. Res. Board Can., 131, 154, 1961.

28. Helm, M. M. and Millican, P. F., Experiments in the hatchery of Pacific oyster larvae (Crassostrea gigas Thunberg), Aquaculture, 11, 1, 1977.

29. Askew, C. G., The growth of oysters Ostrea edulis and Crassostra gigas in Emsworth harbon, Aquaculture, 237, 1972.

30. Walne, P. R. and Mann, R., Growth and biochemical composition in Ostrea edulis and Crassostrea gigas, in Proc. 9th Eur. Mar. Biol. Symp., Aberdeen University Press, 1975, 587.

31. Hall, S., A multiple regression model of oyster growth, Fish. Res., 2, 167, 1984.

32. Kergariou, G., personal communication, 1987.

33. Pacquotte, P. and Moriceau, J., Croissance et indice de condition de l'huître plate Ostrea eduilis élevée en mer et en étang sur la côte meditérranćenne, Haliotis, 16, 427, 1987.

34. Filic, Z. and Krajnovic-Ozretic, M., Novi nalaz Kamenicc Crassostrea gigas (Thunberg) u Limskom Kanalu, Ichthyologica, 10(1), 41, 1978

35. Walne, P. R. and Spencer, B. E., The Introduction of the Pacific oyster (Crassostrea gigas) into the United Kingdom. Shellfish Information Leaflet, No. 21, Ministry of Agriculture, Fisheries and Food, Station Conwy, N. Wales, 1971, 14.

36. Cooke, R. W. T. and Barry, M. D., Growth of the Pacific oyster (Crassostrea gigas) at sites on the East, South, and West coast of Ireland during 1973-1974, Bord lascaigh Mhara Irish Sea Fisheries Board, 12.

37. Shafee, M. G. and Sabatié, M. R., Croissance et mortalité des huîtres dans la lagune Oualidia (Maroc), Aquaculture, 53, 201, 1986.

38. Héral, M., Deslous-Paoli, J. M., and Prou, J., Analyse historique de la production conchylicole du bassin de Marennes-Oléron (France), Coll. Fr. Jpn. Oceanogi., Marseille, Scpt. 16 to 21, (7), 55, 1985.

39. Hughes-Games, W. L., Growing the Japanese oyster (Crassostrea gigas) in subtropical sea water fish ponds. I. Growth rate, survival and quality indes, Aquaculture, 11, 217, 1986.

40. Héral, M., Deslous-Paoli, J. M., and Soruin, J. M., Transferts énergétiques entre l'huître Crassostrea gigas et la nourriture potentielle disponible dans un bassin ostréicole: premières approches, Oceanus, $9(3)$, $169,1983$.

41. Askew, C. G., A generalized growth and mortality model for assessing the economics of bivalve culture, Aquaculture, 14, 91, 1978.

42. Meixner, R., Culture of Pacific oysters (Crassostrea gigas) in containers in Germans coastal waters, in Advances in Aquaculture, Pillary, T. V. R. and Dill, W A., Eds, , Fishing News (Books), Surrey, 1979, 338.

43. Neudecker, T., Untersuchungers des Einflusses von Aufzucht vefahren und standaortbedingten Umneltfaktaren auf den Abwachs von Mollusken, Forschungsberichte Aquakulture, BMFT-FB-M. 84-001 1, 1984, 120 .

44. Seamans, M. N. L., Ecophysiological investigations on the oyster, Crassostrea gigas Thunberg in Flenburg Fjord. Veroeff. Inst. Küsten Binnenfish. Humburg, 89, 71, 1985. 


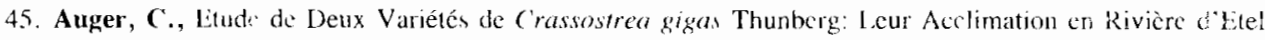
(Morbihan), Thèse Eème cycle Université Paris VJ, 1976, 104.

46. Deslous-Paoli, J. M., Croissance et qualité de l'huître Crassostrea gigas Thunberg én élevag: dans le hassin de Marennes-Oléron, Tethys, I0(4), 365, 1982.

47. Berthomé, J. P., Prou, J., and Bodoy, A., Performances de croissance de l'huitre creuse. Crasscistrea gigas (Thunberg) dans le basin d'élevage de Marcnnes-Oléron entre 1979 et 1982, Haliotis, 15, $183,1986$.

48. Landrein, S., personal communication. 1987

49. Dosdat, A., personal communication, 1987.

50. Bougrier, S. and Deslous-Paoli, J. M., Données de base sur la génétique de l'huître plate Ostrea edulis et de l'huître creuse Crassostrea gigas, in Génétique Quantitative, IFREMER, Paris, 1987, 67

51. Grizel, H., Comps, M., Cousserous, F., Bonami, J. R., and Vago, C., Etude d'un parasite de la glande digestive observé au cours de l'épizootic actuelle de l'huître plate, C. R. Acad. Sci. Paris D, 279, 783, 1974.

52. Pichot, Y., Comps, M., Tige, G., Grizel, H., and Rabouin, M. A., Recherches sur Bonamia ostreae gen. n., sp. n., parasite nouvcau de l'huitre plate Ostrea edulis L., Rev. Trav. Inst. Peches Marit. 43(1), $131,1980$.

53. Héral, M., L'ostréicuiture française traditionnelle, Aquaculture, Barnabé, G., Ed., Lavoisicr, Paris, 1986. 346.

54. Gruet, Y., Héral, M., and Robert, J. M., Premiéres observations sur l'introduction de la faune associée au naissain d'huîtres japonaises Crassostrea gigas (Thunberg) importé sur la côte atlantique française, Cah. Biol. Mar., 17, 173, 1976.

55. Anon., Yearbook of Fishery Statistics, FAO Statistics Series, Vol. 58, Food and Agriculture Organizalion, Rome, 1986

56. Ackefors, H., Mumo, A., Müller, F., and Querellou, J., Development of Aquaculture in Lurope, FAO ERC, 4, Food and Agriculture Organization, Rome, 1986, 31.

57. Dijkema, R., Assessment of size, distribution and composition of a newly developed stock of the European flat oyster (Ostrea edulis) in a stagnant salt water lake in the S. W. Netherlands, ICES Shellfish Committee $K, 14,23,1983$.

58. Dumont, P., Le marché de l'huître creuse. Essai de modélisation économique, Rappon ENGREF, Rennes, 1983,58 .

59. Loosanof, V. L. and Davis, H. C., Rearing of bivalve mollusks. Adv. Mar. Biol. Acad. Press., J(1), 136,1963

60. Walne, R. P., Experimental rearing of the Jarvae of Ostrea edulis L. in the laboratory, Fish. Invest., 2(2). 9 and $23,1956$.

6I. Iucas, A., Development Strategy for Bivalve Hatcheries in Aquaculture Shellish Culture Developınent and Management, IFREMER, Brest, 1987, 249.

62. Grizel, H., Langlade, A., and Perodous, J. B., Premiers essais d'une nouvelle technique de caplage d'huitre plate en baie de Quiberon, ICES, Shellfish Committee K, 24, 14, 1979.

63. Berthomé, J. P., Prou, J., Razet, D., and Garnier, J., Première approche d’une mćthode d'estinalion prévisionnelle de la production potentielle d'huitres creuse Crassostrea gigas d'ćlevage. Haliotis. 14, 39, 1984.

64. Hamon, P. Y. and Tournier, H., Estimation de la biomasse en culture dans l'étang de Thau, Si $i$. Pech' Bull. Inst. Peches Marit., 318, 38, 1981.

65. Zanette, Y. and Garnier, J., Eude prćlininaire de l'impact des huîtres Crassostrea gigas (Thunhergl en élevage sur le biomassé des microorganismes des claires de Marennes-Oléron, ICES, Emironmentul Qucility Committé $L, 14,17,1981$.

66. Robert, J. M., Fertilité des Eaux des Claires Ostréicoles et Verdissement. Utilixation de l'Azotc par les Diatomées Dominantes, Thèse d'Etat. Université de Nantes, 1983, 281.

67 Robert, J. M., Maestrini, S. Y., Héral, M., and Zanette, Y., Production des micro-algues des cla.res ostréicoles en relation avec l'azote organique dissous excrété par les huîtres, Oceanol. Acta $n^{\circ}$ spérial Uneseo Silco, Bordeaux, 389, 1981.

68. Farley, C. A. Banfield, W. G., Kasnic, G., and Foster, W., Oyster herpes-type virus, Science, 178, 759,1972

69. Comps, M. and Duthoit, J. L., Infection virale associée à la "maladie des branchies" de l'huître portugaise Crassostrea angulata Lmk, C. R. Acad. Sci. Paris D, 283, 1595, 1976.

70. Comps, M., Bonami, J. R., Vago, C., and Campillo, A., Une virose de l'huître portugaise, (Crassostrea angulata), C. R. Acad. Sci. Paris D, 282, 1991, 1976.

71. Comps, M. and Bonami, I. R., Infection virale associée à des mortalités chez l'huître Crassostrea gigias Th., C. R. Acad. Sci. Paris D, 285, 1139, 1977

72. His, E., Observations relative à l'infestation de Crassostrea gigas Thunberg per le copépode parasite Myrilicola orientalis Mori dans le bassin d'Arcachon, ICES, Shellfish Committee K, 33, 10, 1977. 
73. His, E., Tige, G., and Rabouin, M. A., Mvtilicolis orientalus Mori dans ic bassin d'Arcauthon, ICES, Shellfish Committec, K14, 12, 1978.

74. Deslous-Paoli, J. M., Mytilicola orienalis Mori, Crassostrea gigas Thunberg's parasite, in the basin of Marennes-Oleron: impaci on the condition and the biochemical composition of oysters during rearing, ICES, Shellfish Committee K, 29, $16 \mathrm{p}, 1981$.

75. Orton, J. H., An account of investigations into the cause or causes of the unusual mortality among oysters in English oyster beds during 1920 and 1921, Minist. Agric. Fish. Fish. Invest., London $2(6), 3$ and 4. 199 and 3, 1924

76. Grizel, H., Etude des récentes épizooties de l'huître plate Ostrea edulis Linne et de leur impact sur l'ostréiculture bretonne, Thése d'Etat, Université des Sciences et Techniques du Languedoc, 1985, 145.

77. Grizel, H., Tige, G., and Rabouin, M. A., Données sur la situation de la maladie de l'huître plate Osirea edulis Lin, ICES, Shellfish Comminee K, 18, 7, 1976.

78. Desportes, I. and Nashed, N. N., Ultrastructure of sponulation in Minchinia denali (Arvi) an Haplasparean parasite of Dentalim Entale (Scaphopoda, Mollusca), Taxonomic Implications, 19, 435, 1983.

79. Comps, M., Observations sur les calses d'une mortalité anormale des huîtres plates dans le bassin de Marennes, Rev. Trav. Inst. Peches Marit, 34(3), 317, 1970.

80. Perkins, F. O., Ultrastructure of sporulation in the European flat oyster pathogen Marteilia refringens, Taxonomic implication, J. Protozool, 23(1), 64, 1976.

81. Franc, A., Sur quelques aspects inédits du cycle de Marteilia refringens Grizel et col, 1974, prarasite de l'huittre plate Ostrea edulis L., Cah. Biol. Mar., 21, 99, 1980

82. Cahour, A., Marteilia refringens and Crassostrea gigas, Mar. Fish. Rev., 41, 19, 1979.

83. Tige, G. and Rabouin, M. A., Etude d'un lot de moules transférés dans un centre touché par l'épizootie affectant l'huître plate, ICES, Shellfish Comminec K, 18, 17 p, 1976.

84. Comps, M., Tige, G., and Grizel, H., Recherches ultrastructurales sur un protiste parasite de l'huitre plate Ostrea edulis L., C. R. Acad. Sci. Paris D, 290, 383, 1980.

85. Grizel, H. and Tige, G., Evojution of the haemocytic disease caused by Bonamia ostreae, Ann. Meet. Soc. Invertebrate Pathologv, September 1, 1982, Brighton, U.K., 254.

86. Van Banning, P., Sone aspects of the occurrence, importance and control of the oyster pathogen Bonamia ostreae, in the Dutch oyster cuiture, in Proc. Int. Coll. Inv. Pathology, September 1982, Brighton, U.K., 261 .

87. Polanco, E., Monte, J., Outon, M. I., and Melendez, I., Situation pathologique du stock d'huîtres plates en Galice (Espagne) en relation avec Bonamia ostreae, Haliotis, 14, 91, 1984.

88. Ackefors, H., International sanitary regulations with reference to aquaculture, ICES Mariculture Committee $F, 45,14,1986$.

89. Deslous-Paoli, J. M., Héral, M., et Massé, H., Bilan énergétique d'une population naturelle de Crepidula fornicata (L.) dans le bassin de Marennes-Oléron. Bases Biologiques de l'aquaculture. Montpellier 1983, Actes Colloq., 1, 109. 124, 1983.

90. Deslous-Paoli, J. M. and Héral, M., Crepidula fornicata L. (gastéropode, colyptraeidae) dans le bassin de Marennes-Oléron: composition et valeur énergétique des individus et des pontes. Oceanol. Actı, 9(3), $305,1986$.

91 Fiala Medioni, A., Ethologie alimentaire d'invertébrés benthiques filtreurs (ascidiés). Il. Variation des taux de filtration et de digestion en fonction de l'espéce, Mar. Biol., 28, 199, 1974.

92. His, L. and Robert, R., Action d’un sel organo métallique l'acétate de trigutyétain sur les oeuf:s et les larves D de Crassostrea gigas (Thunberg), ICES Mariculture Commiltee, F, 27, 10, 1980.

93. Roberl, R. and His, E., Action de l'acétate de tributylétain sur les oeufs et les larves D de deux mollusques d'intérét commercial Crassostrea gigas (Thunberg) et Mytilus galloprovincialis (Lmk) ICES, Maricullure Committee, $F, 42,16,1981$

94. Alzieu, C., Héral, M., Thibaud, Y., Dardignac, M. J., and Feuillet, M., Influence des peintures antisalissures á base d'organo stanniques sur la calcification de la coquille de l'huître Crassostrea gigas, Rev. Trav. Inst. Peches Marit., 45(2), 101, 1982.

95. Héral, M., Berthomé, J. P., Polanco Torres, E., Alzieu, C., Desious-Paoli, J. M., Razet, D., and Garnier, J., Anomalies de croissance de la coquille de Crassostrea gigas dans le bassin de MarennesOléron. Bilan de trois années d'observations, ICES, Shellfish Commiltee K, 31, 16, 1981.

96. Alzieu, C. and Héral, M., Ecotoxicological effects of organotin compounds on oyster culture, in Ecotoxicological Testing for the Marine Environment, Vol. 1, Persoone, G., Jaspers, E., and Claus, C., Eds. , State University of Ghent and Inst. Mar Sci. Res., Bredene, Belgium, 1983, 187.

97. Waldock, M. J. and Thain, J. E., Shell thickening in Crassostrea gigas: organotin antifouling or sed.ment induced, Mar. Pollut., 14, 411, 1983.

98. Thain, J. E. and Waldock, M. J., The growth of bivalve spat exposed to organotin leachates from antifouling paints, ICES, Marine Environmentai Committec E, 13, 5, 1985.

99. Héral, M., Alzieu, C., and Desious-Paoli, J. M., Effects of organotin compounds (TBT) used in antifouling paints on cultured marine molluses: a literature study, in Proc. Aquaculture Europe 87, Jaspers, E. . Ackefors. H., and Wilkins. N., Eds, in press 
100. Bonnicux, K., Daace, P., and Ranelli, P., Impact socio-conomigue de la mare noire provenant de I'Ankeo-Cadiz, Rapport INRA-U V.L.O.t., 1980, !00.

101. Meuriot, F. and Grizel, H., Note sur l'impact ćconomiçue des maladies de l'huître plate en Brelagre, unpublished data, 1988, 18.

102. Gowen, R. J., Toxic phyloplankton in Scottish coastal waters, Rapp. P. V. Reun. Cons. Int. Explor. Mer. 187,89 and $93,1987$.

103. Tangen, K., The effects of phytoplankton blooms on mariculture in Norway, Rapp. P V. Reun. Cons. Int. Explor. Mer, 187, poster D: 1, 1987

104. Fraga, S., Marino, J., Bravo, I., Miranda, A., Campos, M. J., Sanchez, F. J., Costas, E., Cabanas, J. M., and Blanco, J., Red tides and shellfish poisoning in Galicia (NW Spain), Rapp. P. V. Reun. Cons. Int. Explor. Mer C, 187, 5, 1987.

105. Moita, M. T., Cunba, M. E., and Sampayo, M. A. M., Portuguese coustal red waters, Rapp. $P . V$. Reun. Cons. Int. Explor. Mer B, 187, 9, 1987

106. Parker, M., Exceptional plarkton blooms, conclusions of discussions: Conener's report, Rapp. P. V. Kenn. Cons. Int Explor. Mer, 187, 108, 1987.

107. Lassus, P., Bilan des eaux colorées observées sur le littoral française entre 197.5 et 1982, /CES, Envirunmental Committee L, 29, 1987.

108. Kat, M., Diarthetic mussel poisoning, Rapp. P. V. Reun. Cons. Int. Explor. Mer, 187, 83, 1987.

109. Dunne, T., Doyle, J., and Parker, M., Review of the incidence and effects of unustal marine blooms in Irisls coastal waters 1976-1984. Rapp. P. Y. Reun. Cons. Int. Explor. Mer, 187, poster D: 9, 1987.

110. Caumette, P. and Baleux, B., Etude des equx rouges dues à la prolifération des bactéries photosynthétiques sulfoxydantes dans l'étang du Prévôt (lagune saumâtre méditerranéenne), Mar. Biol., 56, 183, 1980.

111. Coeurdacier, J. L., Réserves d'eau de mer et dégorgeoirs. Equinoxe, 8(6), 11, 1986.

112. Anon., Recommended International Code of Practice for Molluscan Shellish, Joint IAO/WHO Standarcis Programme, Codex Alimentarius Commission, CAC/RCP, 18, 1978, 23.

113. Anon.. Directive du Conseil du 30 octobre 1979 relative à la qualité requise des equx conchyliocoles $79 /$ 923/CEE. J. Off. Commun. Eur., 10.11.79. L 281, 47, 6 p, 1979.

114. Aure, T., Müller euga, A., Priour, La mytriculture on mer ouverte, Cultures Mar., 145, 4, 1987

115. Priour, Matériels conchylicoles: quoi de neuf? Equinoxe, 9, 23, 1986

116. Mialhe, E., Boulo, E., Grizel, H., Kogier, H., and Paolucci, F., Monocional antibodies: a new tool in molluscan pathology, in Disease Processes in Marine Bivalve Molluscs, Spec. Publ. Ser.. Anerican Fisherie: Society, in press.

117. Mialhe, E., Bachére, E., Chagot, D., and Grizel, H., Isolation and purification of the protozoan Bonamia ostrae (Pichot and Coll, 1979), a parasite affecting the flat oyster Ostrea edulis L., Aquaculture, in press.

118. Boulo, V., Rogier, H., Paolucei, F., Mialhe, E., and Grizel, H., Immunodiagnostic of Bonamia ostrea (Ascetospora) parasite of Ostrea edulis and subcellular identification of epitopes by monoclonal antibodies. J. Fish Dis., in press.

119. Cochennec, N., Boulo, V., Mialhe, E., Grizel, H., Rogier, H., Clavies, C., Hervand, E., Pau, B., Puygrenier, M., and Paolucci, F., Use of monoclonal antibody in an enzyme immunoassay for the detection of Bonamio ostrea in the hemolymph of flat oysters, Ostrae edulis, 3rd Int. Conf. European Association of Fish Pathologists, September 1987, Bergen, in press.

120. Bacher, C., Baud, J. P., Bodoy, A., Deslous-Paoli, J. M., Dréno, J. P., Héral, M., Maurer, D., and Prou, J., A methodology for the stocks assessments of cultivated oysters along the French Alantic coasts, ICES, Shellfish Comunittee $K, 36,14,1986$.

121. Deslous-Panli, J. M., Populus, J., L'Herroux, M., and Brussieux, M., Estimation des stocks cochylicoles par télédétection: résultats et perspectives, Coll. Fr. Ipn. Oceanogr, Marseille September 16-21, 1985, 7. 39,1985

122. Deslous-Paoli, J. M. and Héral, M., Transferts énergétiques entre l'huître Crassostrea gigas de I an et la nourriture potentielle disponible dans l'eau d'un bassin ostréicole, Haliotis, 14, 79, 1984.

123. Bacher, C., Modélisation de la Croissance de Huitres dans le Bassin de Maremnes-Oléron, Rapp. IFREMER, 1987,12

124. Quillett, Et. and Panelay, P. J., Triploidy induction by thermal shocks in the Japanese oyster, Crassostrea gigas, Aquacullure, 57, 271, 1986

125. Downing, S. L. and Allen, J. K., Induced triploidy in the Pacific oyster, Craswoverea gigas: optimal teatments with Cytochalasin B depend on temperature, Aquaculture, 61, 1, 1987.

126. Gilly, B. and Meuriot, E., Bio-Economic Analysis of Shellfish-Culture Activity in France: Prospect and Limits in Aquaculture, Shellfish Culture Development and Management, IFREMER, Brest, 1987, 367. 